AperTO - Archivio Istituzionale Open Access dell'Università di Torino

Calcareous nannofossil and foraminiferal trace element records in the Sorbas Basin: A new piece of the Messinian Salinity Crisis onset puzzle

This is a pre print version of the following article:

Original Citation:

Availability:

This version is available http://hdl.handle.net/2318/1770443

since 2021-02-01T12:35:33Z

Published version:

DOI:10.1016/j.palaeo.2020.109796

Terms of use:

Open Access

Anyone can freely access the full text of works made available as "Open Access". Works made available under a Creative Commons license can be used according to the terms and conditions of said license. Use of all other works requires consent of the right holder (author or publisher) if not exempted from copyright protection by the applicable law. 


\title{
Calcareous nannofossil and foraminiferal trace elements records in the Sorbas basin: a new piece of the Messinian Salinity Crisis puzzle
}

\author{
Alan Maria Mancini, Rocco Gennari, Patrizia Ziveri, P. Graham Mortyn, Davey Joey \\ Stolwijk, Francesca Lozar \\ DOI: https://doi.org/10.1016/j.palaeo.2020.109796
}

Accepted date: 8 May 2020

Please cite this article as: A.M. Mancini, R. Gennari, P. Ziveri, et al., Calcareous nannofossil and foraminiferal trace element records in the Sorbas Basin: A new piece of the Messinian Salinity Crisis onset puzzle, Palaeogeography, Palaeoclimatology, Palaeoecology (2019), https://doi.org/10.1016/j.palaeo.2020.109796

\begin{abstract}
The Messinian Salinity Crisis (MSC) was an extreme event that affected the Mediterranean Sea during the late Miocene, leading to massive evaporite deposition across the basin. Here we focus on the Perales section (Sorbas Basin, Western Mediterranean), using calcareous nannofossil (CN) and foraminiferal geochemical analyses to trace the paleoenvironmental dynamics before and at the MSC onset.

Orbital and tectonic forces drove the $\mathrm{CN}$ fluctuations that correlated with the lithological quadripartite precessional cycle. Our integrated analysis reveals that the cyclical sapropel deposition started with an increase in marine productivity, followed by an increase in freshwater input and the development of a Deep Chlorophyll Maximum (DCM). The overlying marl records the protracted freshwater input that led to the shallowing of the DCM, decreasing organic carbon export and promoting sea floor re-oxygenation. Stratification, acting as a barrier, trapped part of the riverine delivered nutrients below the photic zone. The subsequent gradual decrease in temperature promoted the disruption of the stratification, redistributing nutrients in the photic zone and promoting diatoms proliferation and the diatomite deposition. When the reservoir of dissolved silica was exhausted, bioturbated marl were deposited at the top of the cycle.

In the last pre-evaporitic cycle (UA34) the lithological cyclicity is obliterated, however the precessional footprint is revealed by $\mathrm{CN}$ fluctuation, suggesting that sapropel-like deposition took place for most of the cycle. This cycle also records a succession of CN abundance peaks (MSC-CN bioevent), as already recorded in several section approximately at the MSC onset, suggesting that the same paleoenvironmental changes triggered the evaporitic phase in the whole Mediterranean. This bioevent marks the last step of water
\end{abstract}


exchange reduction with the Atlantic (restriction pulse), that increased the sensitivity of the Mediterranean to the freshwater input and the associated nutrients delivery, culminating in a further increase in marine productivity.

\section{1-Introduction}

The Messinian is a geological stage characterized by rapid and extreme environmental changes affecting the whole Mediterranean region, mostly related to the ongoing restriction of the Atlantic gateways (Flecker et al., 2015). The progressive restriction is suggested to be one of the main triggers of the onset of the MSC, which started synchronously in the whole Mediterranean at 5.97 Ma (Manzi et al., 2013). The MSC onset is marked by the deposition of primary gypsum at shallow to outer shelf depths and gypsum free euxinic shales or carbonates in deeper basins (Roveri et al., 2014 and references therein). The ongoing restriction amplified the sedimentary and ecological response to orbitally induced climatic variation (Hilgen and Krijgsman, 1999). A series of steps marking the paleoceanographic evolution before the MSC onset are recognised in the fossil record in many sections across the Mediterranean (Sierro et al., 2001; 2003; BlancValleron et al., 2002; Kouwhenoven et al., 2006; laccarino et al., 2008; Gennari et al., 2018). These major steps in the Mediterranean paleoceanographic evolution are dated at 7.19, 6.7, 6.4- 6.29, and 6.1-6.0 Ma (Kouwhenoven et al., 2006 and references therein). The second restriction at 6.7 Ma amplified the sensitivity of the Mediterranean to the precessional forcing, which drove the rhythmic deposition of sapropels at each insolation maximum (Sierro et al., 2003).

The Sorbas Basin represents one of the most intensively studied Messinian basins (Troelstra et al., 1980; Martin and Braga, 1994; Baggley, 2000; Fortuin et al., 2000; Sierro et al., 2001; Sierro et al., 2003; PerezFolgado et al., 2003; Vazquez et al., 2003; Filippelli et al., 2003; Flores et al., 2005; Braga et al., 2006; Rodrìguez-Tovar et al., 2013; Clauzon et al., 2015; Modestu et al., 2017; Reghizzi et al., 2017). However, most of the high resolution micropaleontological studies focused only on the lower part of the UA (from cycle UA5 to UA8, i.e. from $\cong 6.6 \mathrm{Ma}$ to $\cong 6.55 \mathrm{Ma}$ ) with the long-term trend toward the MSC onset being documented with foraminiferal and isotopic (Oxygen, Carbon and Strontium) dataset only (Sierro et al., 2003; Reghizzi et al., 2017). This paper aims to track the environmental changes spanning the uppermost pre-MSC (from 6.226 Ma) and the MSC onset by comparing previously published data with newly produced $\mathrm{CN}$ abundance fluctuations and trace elements analysis of the foraminifer Orbulina universa in the Perales section. The sensitivity of $\mathrm{CN}$ as an environmental proxy in this time interval is supported by previous results showing $\mathrm{CN}$ abundance peaking (here named "MSC-CN bioevent") approximating the time of the MSC onset in several Mediterranean successions (Lozar et al., 2018; Manzi et al., 2018; Lozar and Negri, 2019). To decipher this peculiar CN signal is of a paramount importance in order to constrain which paleoenvironmental changes triggered the MSC onset. 


\section{Materials and methods}

\subsection{Pre MSC deposits}

The Abad marls are deposited in the central part of the Sorbas Basin (Martin and Braga, 1994); they were deposited from the base of the Messinian and are overlain by primary evaporites of the Yesares Formation. Based on the different lithologies, the Abad marls can be divided into two units: the Lower Abad and the Upper Abad (LA and UA units, respectively; Sierro et al., 2001). Both units record the precessional signal, but differs in its lithological expression: the LA are characterized by an alternation of indurated, homogeneous whitish marls and softer homogeneous grey marls rich in planktonic foraminifers (Sierro et al., 2001); the UA deposits are characterized by a quadripartite cycles (sapropel - marl - diatomite - marl). As outlined by Sierro et al. (2001), exceptions from this rule coincide with peculiar orbital curve conformations, corresponding to eccentricity minima or precession/obliquity interference giving rise to low or high insolation amplitude.

The sapropels in the Sorbas Basin are sandwiched between homogeneous white marl beds and consist of brownish laminated marls with silty to sandy thin turbidite beds intercalations. Generally, the lamination is well developed in the upper part of the sapropels, whereas it is weakly developed in the lower parts, where bioturbation is slightly more intense (Sierro et al., 2001; Flores et al., 2005). The diatomites are white, usually laminated and with a high abundance of diatoms frustules.

We re-sampled the Perales A and C subsections of Sierro et al. (2001), including the transitional interval detailed in Manzi et al. (2013), up to the base of the lowermost PLG cycle. Regarding the UA cycles, some subtle differences emerged during the field work, but a robust correlation is maintained by the identification of thick/thin sapropelitic or diatomitic layers and by foraminiferal bioevents and trend (Fig.2). Taking advantage of the very good outcrop condition, we were able to produce a detailed log of the transitional interval ("transition to the gypsum interval" in Sierro et al., 2003; upper UA34 cycle in Manzi et al., 2013), which introduces new and important features, which are detailed in section 2.2.

\subsection{The UA34 case}

A general deviation from the "regular" quadripartite cycle is represented by the cycle UA34, which, from bottom to top, is composed of sapropel - spiculite - from weak to well laminated sapropel - limestone from weak to well laminated sapropel - limestone - clay (Fig.2). The lack of the diatomitic layer and the weak differences, in terms of colour and lamination between sapropel and marls compared to the underlying cycles, complicate the recognition of the precessional forcing. The clay at the top of cycle UA34 
is located just below the base of the poorly laminated to laminated sapropel below the base of the first gypsum layer.

\subsection{Calcareous nannofossil analysis}

Standard smear-slides were prepared for each collected sample and observed at 1250X by polarized light microscopy. In each slide at least 500 specimens were counted and identified. The $\mathrm{CN}$ preservation ranges from poor to good; overall cycles UA29 and UA30 are characterized by poor CN preservation. The rare and the extremely rare species without known paleoecological significance are not shown in figures 4.1 and 4.2. Reticulofenestra pseudoumbilicus $<7 \mu \mathrm{m}$ and $>7 \mu \mathrm{m}$, Calcidiscus leptoporus $<7 \mu \mathrm{m}$ and $>7 \mu \mathrm{m}$, Pontosphaera multipora, Pontosphaera japonica, Discoaster variabilis, Discoaster brouweri, Discoaster pentaradiatus, Sphenolithus abies and Sphenolithus moriformis are included in the informal groups of $R$. pseudoumbilicus gr., C. leptoporus gr., Pontosphaera gr., Discoaster gr. and Sphenolithus gr., respectively. The informal group Sphenolithus gr. mainly comprises S. abies, whereas S. moriformis has a scattered occurrence and shows considerable abundance only in a few intervals. The presence/absence of diatom in the $\mathrm{CN}$ counting phase was performed as well. Scanning electronic microscopy (SEM) analyses were performed on selected samples of the cycle UA34 using a JSM-IT300LV SEM equipped with an energydispersive EDS Oxford Instrument Link System microprobe (Department of Earth Sciences, University of Torino)

\subsection{Foraminiferal analysis}

In order to correlate our log with the Abad composite section published in Sierro et al. (2001), planktonic foraminifer assemblages were observed in some selected samples (20 samples from UA25 to UA31). About 100 grams of sample, previously dried, were soaked in diluted $\mathrm{H}_{2} \mathrm{O}_{2}$ for one day; successively the sediment was washed using a $63 \mu \mathrm{m}$ sieve, oven-dried, and dry-sieved to obtain 3 different size fractions: $>500 \mu \mathrm{m}$, 500-125 $\mu \mathrm{m}$ and 125-63 $\mu \mathrm{m}$. Qualitative analyses were carried out on $>125 \mu \mathrm{m}$ residues. A qualitative analysis (presence/absence) of planktic and benthic foraminifers was performed as well in the cycle UA34 (Fig.5)., which was not the object of previous studies

\subsection{Orbulina universa trace element analysis: a new picking protocol}

31 samples taken throughout the studied interval (2-3 samples each cycle) were prepared for the trace element analyses. A major challenge of the foraminiferal trace element analyses was the poor preservation of the $O$. universa calcite shells, often filled with diagenetic calcite (Fig. $3 \mathrm{D}, \mathrm{E}$ and F). This diagenetic calcite overprint could potentially bias the overall trace element signals inherent to the biogenic calcite of the foraminifer shells. To avoid this contamination, we focused only on well-preserved $O$. universa, using a new picking technique as follows: 
-Wash the sediment in a sieve (we used the $63 \mu \mathrm{m}$ ) using ELIX water (this water is to be preferred because it prevents the precipitation of carbonate crystals) sprayed with a pump.

-When the fine fraction is washed away, oven-dry the sample $\left(70 \mathrm{C}^{\circ}\right)$.

-Sieve the sediment of the target size range (the one we aim to measure). In this work, we focused on the foraminifer size between 315 and $355 \mu \mathrm{m}$. Take the target size fraction and put it in a beaker previously filled with ELIX water. Let the heavier foraminifers (filled or encrusted by secondary calcite) rapidly sink.

- Aspirate the floating shells with a pipette. This allows capturing the lighter shells that are likely devoid of diagenetic calcite or sediment infill.

-Put the captured foraminifers into a saucer and proceed to picking while the foraminifers are still wet. This procedure improves the possibility to pick pristine shells, since wet foraminifers (especially 0 . universa) better show their transparency, and more transparent tests are usually devoid of secondary calcite.

We further tested the reliability of this method by checking SEM pictures of both the heavier/sinking $O$. universa (Fig.3 D, E, F) and the lighter/floating ones (Fig.3 A,B, C). The test indicates that our methodology assures to capture the best preserved $O$. universa specimens.

\subsection{Orbulina universa trace element analyses}

The investigated samples were composed of a minimum of $100 \mu \mathrm{g}$ of shell calcite of $O$. universa picked from sapropel and lower marls. In most cases, the well-preserved $O$. universa picked did not provide the calcite weight needed for the analysis (100-150 $\mu \mathrm{g}$ of calcite); this restricted our analysis to only 14 samples in the UA23-base UA30 interval and in the transition from UA32 to UA33. The samples were cleaned according to the "Cd method" described by Rosenthal et al., 2004. The method consists of several steps: clay removal washes (water and methanol), a reductive step (ammonium hydroxide, citric acid and hydrazine hydrate), an oxidative step (sodium hydroxide and hydrogen peroxide), and finally a weak acid leach (nitric acid). The samples were analysed with an inductively coupled plasma mass spectrometer (ICPMS, Agilent model 7500ce) at the Autonomous University of Barcelona. The procedure of data reduction followed that previously establish by Yu et al., 2005.

According to the premise that the seawater temperature is the primary control on $\mathrm{Mg}^{2+}$ incorporation in the foraminiferal calcite shell during the calcification process, the $\mathrm{Mg} / \mathrm{Ca}$ analysis is often used as a $\mathrm{T}$ proxy (Lea et al., 1999; Elderfield \& Ganssen, 2000; Erez, 2003; Barker et al., 2005). The obtained Mg/Ca values were converted into temperature values according to Anand et al., (2003) using the equation:

$\mathrm{Mg} / \mathrm{Ca}=\mathrm{B} \exp (\mathrm{AT})$

where $\mathrm{Mg} / \mathrm{Ca}$ is the measured value from the calcite shell, $\mathrm{A}$ and $\mathrm{B}$ are constant coefficients (corrected for O. universa according to Anand et al., 2003 Table 3) and T is the calcification temperature.

Early studies reported that foraminifers can sequester barium and other elements in proportion to their concentration in the surrounding seawater (Boyle and Keigwin, 1985; Lea and Boyle, 1991). Consequently, 
the trace element studies are considered reliable proxies for ocean elements reconstruction in the past. Apart from hydrothermal vents, the major source of barium to the ocean is fluvial discharge (Martin and Meybeck, 1979). Moreover, the input of fluvial barium increases in the river-sea mixing zone as barium desorbs from the suspended load by ion exchange (e.g. Hanor and Chan, 1977). For these reasons, high levels of barium in surface seawater track continental inputs, consequently the measured $\mathrm{Ba} / \mathrm{Ca}$ on foraminiferal shell is used here as a continental run-off proxy.

\section{Results}

\subsection{Calcareous nannofossil relative abundance}

The $\mathrm{CN}$ assemblage is composed of 28 calcareous nannofossil taxa (appendix). $\mathrm{CN}$ are present throughout the studied interval, except in all the samples collected above the second limestone layer of cycle UA34. The composition of $\mathrm{CN}$ assemblages is cyclical and quite regularly follows the lithological cyclicity. CN assemblages are generally dominated by Reticulofenestra minuta, which is present in all samples and commonly reaches up to $60 \%$ of the total assemblage. $R$. minuta usually shows minimum abundance in the diatomite, where it is often replaced by R. pseudoumbilicus sp. and Reticulofenestra haqii. Sphenolithus gr. show abundance peaks in the middle-upper part of the sapropel (ca. 30\%) and an abundance maximum at $62 \%$ in the spiculite layer of the cycle UA34. Conversely, Sphenolithus gr. minimum abundance is recorded in the diatomite layer. Sphenolithus gr. also show a positive correlation with the temperature inferred from the $\mathrm{Mg} / \mathrm{Ca}$ analysis. Helicosphaera carteri occurrence is scattered but shows prominent peaks in abundance (more than $30 \%$ ) generally associated to the diatomite layer. High $\mathrm{H}$. carteri abundance $(55 \%)$ is found concurrently with a prominent $\mathrm{Ba} / \mathrm{Ca}$ peak in the lower marls of the cycle UA30. Coccolithus pelagicus and R. pseudoumbilicus gr. show a similar trend, with peaks in abundance close to the diatomite and a progressive increase at the top of UA34. C. leptoporus gr. is mainly composed of large morphotye (according to Quinn et al., 2004), its higher abundances is generally found in the upper marls. Umbilicosphaera rotula abundance never exceeds $24 \%$ of the total assemblage and shows peaks preferentially in the upper marl-sapropel transitions. The most prominent $U$. rotula peaks $(24 \%$ at the base of the sapropel in UA24; $17 \%$ and $15 \%$ in the poorly/well laminated sapropels of the cycle UA34) coincide with the maximum abundance of benthic foraminifers recorded by Sierro et al., 2003 and in our material (Fig.5). Rhabdosphaera clavigera abundance is generally low and never exceeds $4.5 \%$, aside from the cycle UA28 where three different peaks are recorded (from $4.5 \%$ to $9 \%$ ), occurring together with $C$. leptoporus gr. and C. pelagicus peaks. From cycle UA28 R. clavigera shows a decreasing trend toward the top of the section. $R$. haqii abundance is scattered and apparently does not correlate with the lithology. In cycles UA32 and UA33 the higher $R$. haqii abundance is recorded in few samples (from $40 \%$ to $88 \%$ ). Similar to $R$. haqii, $R$. antarctica abundance is generally low, but shows a prominent peak (and other minor peak) in 
cycles UA32 and UA33. Umbilicosphaera jafari abundance is generally low but occurs in high abundance in some discrete intervals (from UA23 to UA25 and from UA31 to UA33), exceptionally reaching $87 \%$ of the assemblage in the upper marl of the UA24. Pontosphaera gr. is regularly present in moderate abundance generally in the diatomite up to cycle UA31, where it starts to decrease. Syracosphaera sp. 1 is preferentially present close to or in the diatomite, with an abundance that never exceeds $22 \%$ (cycle UA28) and generally is below $5 \%$. The abundance of Discoaster gr. is scattered but shows prominent peaks, recorded preferentially in the upper marl, up to cycle UA28; it becomes rare above this level. Intriguingly, Discoaster gr. are present in some levels (lower marls of the cycles UA23, UA24, UA26 and in the sapropel of the cycle UA31) with moderate abundance; their poor preservation and strong recrystallization hinders the identification at the species level and consequently the discrimination between synsedimentary and reworked specimens. This probably results in an underestimation of the Discoaster gr. abundance, especially in the upper part of the section. Thoracosphaera heimii shows a scattered abundance, with a maximum in abundance in UA34 $(1,4 \%)$.

The relationship between the CN assemblage and the lithological cyclicity changes in cycle UA34, where a sequence of abundance peaks of peculiar species (here named MSC-CN bioevent; Fig. 4) is recorded, as previously reported in other sections, approximating the MSC onset (Lozar et al., 2018; Lozar \& Negri, 2019). The succession of peaks in abundance is composed of: S. abies, followed by U. rotula, H. carteri. S. abies (during the MSC-CN bioevent the informal Sphenolithus gr. is composed entirely of S. abies) peaks $(62 \%)$ in the spiculite layer; $U$. rotula shows 2 peaks (17\% and 15\%) recorded in poorly laminated sapropel and in a laminated sapropel immediately above the S. abies peak. H. carteri gradually increases at the base of UA34 and peaks (33\%) in a poorly laminated sapropel above the U. rotula peak. Above the MSC bioevent, C. pelagicus and R. pseudoumbilicus gr. increase up to the second limestone of the UA34 cycle, where suddenly all CN disappear.

\subsection{Trace elements analysis $(\mathrm{Mg} / \mathrm{Ca}$ and $\mathrm{Ba} / \mathrm{Ca})$}

The obtained $\mathrm{Mg} / \mathrm{Ca}$ values span from $1.205 \mathrm{mmol} / \mathrm{mol}$ to $3.448 \mathrm{mmol} / \mathrm{mol}$ and correspond to temperatures ranging from $9.5^{\circ} \mathrm{C}$ to $19.7^{\circ} \mathrm{C}$. A long term temperature trend toward the MSC onset is not discernible in our results. The recognition of temperature trends is biased by the low stratigraphic resolution obtained in the upper portion of the studied section; however, it is still possible to observe oscillation in phase with precessional climatic variation, with higher values $\left(17.5^{\circ} \mathrm{C}-19.2^{\circ} \mathrm{C}\right)$ during the upper part of the sapropel deposition in cycles UA23, UA25 and UA33. Low temperature values are recorded in the middle part of the sapropel in UA28 $\left(8.1^{\circ} \mathrm{C}\right)$ and in the upper marl roughly at the marl- 
sapropel transition in UA29 $\left(10.4^{\circ} \mathrm{C}\right)$. The lower marls are characterized by low temperature values in the cycles UA23, UA24 and UA30 $\left(7.8^{\circ} \mathrm{C}-9.6^{\circ} \mathrm{C}\right)$, mild value in UA32 $\left(15^{\circ} \mathrm{C}\right)$ and high value in UA28 $\left(19.7^{\circ} \mathrm{C}\right)$. The $\mathrm{Ba} / \mathrm{Ca}$ values generally span from $0,125 \mu \mathrm{mol} / \mathrm{mol}$ to $0,349 \mu \mathrm{mol} / \mathrm{mol}$. The higher value $(0,733$ $\mu \mathrm{mol} / \mathrm{mol}$ ) is recorded in the lower marls of the cycle UA30. The obtained Ba/Ca values are systematically lower compared to the O. universa $\mathrm{Ba} / \mathrm{Ca}$ results obtained by Sprovieri et al. (2008; Falconara section, Sicily, Italy); this reflects more arid conditions in the Sorbas Basin compared to Falconara, probably due to African rivers influence (Griffin, 2002) in the southern Mediterranean. Subtle oscillations are recorded in the UA23UA29 interval, where slightly lower values are associated with the sapropels and relatively higher values are documented for the lower marls, with the outstanding high values of cycle UA30.

\section{4- Discussion}

\subsection{Paleoecology of selected Calcareous Nannofossil taxa}

Understanding the paleoecological preferences of the species involved in the MSC-CN bioevent is of paramount importance for deciphering the paleoenvironmental changes occurred at, and driving the MSC onset. The interpretation of the Messinian $\mathrm{CN}$ abundance fluctuation is complicated because many of these species are extinct and their ecological preferences are poorly understood. Here, we discuss the paleoecological preferences of the CN taxa involved in the MSC-CN bioevent in the light of information gathered from previous studies and from this work (summarized in Fig. 7).

\section{Sphenolithus gr.}

A wide range of paleoecological preferences has been attributed to the extinct Sphenolithus spp. It is generally described as adapted to warm, stratified and oligotrophic environments during the Cenozoic (Perch Nielsen, 1985), from the Upper Eocene to the Upper Miocene (Mejia-Molina et al., 2010) and during the Pliocene (Gibbs et al., 2004), with a deep photic zone preferred habitat (Gibbs et al., 2004). Furthermore, Sphenolithus gr. is also regarded to prefer either open and well oxygenated marine conditions during the late Paleogene (Aubry et al., 1992) or marginal environments with freshwater influxes during the Burdigalian of the Northern Alpine foredeep (Auer et al., 2014). During the Messinian, Sphenolithus gr. is widely reported in the Mediterranean pre-evaporitic marls (Blanc-Valleron et al., 2002; Kouwhenhoven et al., 2006; Gennari et al., 2018; Flores et al., 2005; Lozar et al., 2018) and interpreted as a deep photic zone dwellers (Flores et al., 2005), an opportunistic and mesotrophic taxon by Wade and Bown (2006) and adapted to high salinity fluctuations and to a shallow environment (Lozar et al., 2010). In the lower UA5UA8 cycles, maxima in Spenolithus gr. abundance occurs in the middle lower part of the sapropels, and this taxon is replaced in the middle-upper part by Discoaster gr. (Flores et al., 2005). 
Our data show a cyclical increase in Sphenolithus gr. abundance in the middle-upper part of the sapropels, however, in our samples Discoaster gr. are often poorly preserved and recrystallized, hampering the identification of the turnover recorded by Flores et al. (2005). Sphenolithus gr. High abundances are also retained in the upper marls of cycles UA27 and UA28, centred on the 6.14 Ma $100 \mathrm{Kyr}$ eccentricity minimum, which correspond to a prolonged insolation maxima phase during an interglacial stage (Laskar et al., 2004). Sphenolithus gr. abundance is suppressed during the glacial isotope stages (red arrows in Fig. 4.1) inferred from the benthic and planktic $\delta^{18} \mathrm{O}$ in the Ain el Beida section (Morocco, van der Laan et al., 2005). In our data, Sphenolithus gr. show a positive correlation with the temperature inferred from $\mathrm{Mg} / \mathrm{Ca}$ (despite the lower resolution of this proxy), in agreement with previous studies (Haq and Lohmann 1976; Lohmann and Carlson, 1981; Flores and Sierro, 1987; Flores et al., 1995; Castradori, 1998; Flores et al., 2005); this correlation is further supported by the dominance of warm oligotrophic foraminifers, which indicate the formation of a strong and permanent pycnocline at depth with the subsequent stratification of surface waters (Sierro et al., 2003). All these features suggest a robust temperature control on Sphenolithus gr. abundance. This is further suggested by scarcity of these taxa in the Northern Mediterranean preevaporitic successions (Piedmont basin and northern Apennines), where the Sphenolithus gr. abundance exceed $20 \%$ only during the MSC bioevent (see section 5.4 ).

However, the notable abundance differences of the Sphenolithus gr. peaks in the sapropelitic layers of the adjacent Tokhni (present in all the sapropel layers) and Pissouri (low and scattered occurrence) sections in the eastern Mediterranean allows to rule out the temperature as the only factor controlling the abundance fluctuations of Sphenolithus spp. Furthermore, in the evaporitic phase of the Messinian Polemi section (Cyprus), Wade \& Bown (2006) recorded high abundances of Sphenolithus gr. in diatom rich layer, suggesting the ability of this species to thrive in mesotrophic environments. Similar diatom-Sphenolithus coupling assemblage were found in the Moncalvo section (Lozar et al., 2018). This further suggests that Sphenolithus gr. abundance is not only controlled by the water temperature, but also by other environmental parameters, such as nutrient availability in the water column (deep vs shallow, oligotrophic vs eutrophic).

\section{Umbilicosphaera rotula}

Ziveri et al. (2004) reported that the living relatives of U. rotula, Umbilicosphaera sibogae var. sibogae and Umbilicosphaera sibogae var. foliosa mostly occur under oligotrophic and mesotrophic conditions, respectively. Guerreiro et al. (2014) suggest that Umbilicosphaera gr. is an upper photic zone dweller. Alves et al. (2016) use the genus Umbilicosphaera as a proxy for eutrophic conditions, due to the negative correlation with the oligotrophic genus Discoaster in the Miocene record of the Campos Basin (Brasil). Flores et al. (2005) recorded the U. rotula maximum abundance preferentially in the Sorbas upper marls. 
These authors suggest that $U$. rotula was able to thrive in surface waters where nutrients become depleted after diatoms blooms, in a stable pycnocline development regime. In our longer record, U. rotula is present in the upper marls as well, but maxima in abundance are also recorded in the upper marls-sapropel transition (base UA24, UA29 and UA32). The upper marls-sapropel transition (especially from UA17 upwards) are deposited under severe conditions, as suggested by the absence of planktic foraminifer, pointing to the ability of $U$. rotula to thrive also in a "stressed" environment. The "stressed" condition may be related to eutrophic surface water (Sierro et al., 1999; 2003).

The finding of $U$. rotula high abundance, engulfed in a silica-rich matrix arranged in clusters, in the sediments recording the MSC-CN bioevent (this study, Fig. 6; Pollenzo section, Natalicchio et al., 2019) suggests that $U$. rotula was mainly transported to the sea floor by sinking fecal pellets. Fecal pellets are component of the marine snow, formed in the upper oxygenated layers during episodes of enhanced productivity (Alldredge and Silver, 1988; Dela Pierre et al., 2014). The finding of benthic foraminifers such as Bolivina gr. and Bulimina echinata concomitant with $U$. rotula peaks suggests high productivity in the water column and high organic matter export to the sea floor. This situation is exacerbated in cycles UA24 and UA34, where $U$. rotula peaks are accompanied by very abundant benthic foraminifers (Sierro et al., 2003; this study Fig. 5). This supports our interpretation that $U$. rotula was able to flourish in high abundance in eutrophic conditions.

\section{Rhabdosphaera clavigera}

R. clavigera is a living taxon; it is reported as a warm water species that proliferates in oligotrophic surface conditions (Ziveri et al., 2004); it has an opportunistic behaviour and does not tolerate low light irradiance levels (Haidar \& Thierstein, 1997; Malinverno et al., 2003); it has a preference for a stable and stratified water column, not tolerating turbulence (coastal proximity and/or upwelling) (Silva et al., 2008). In the late Quaternary sapropels, the increase of Rhabdosphaera spp. and Florisphaera profunda are positively correlated (Castradori, 1992; Negri et al., 1999a, b), suggesting some connection with the Deep Chlorophyll Maximum (DCM) development. The R. clavigera-sapropel relationship was recorded in the lower cycles of the UA (Flores et al., 2005), while is not evident in our results. Our data show a scattered distribution, with few prominent peaks $(3 \%-8 \%)$ in the upper and lower marls and in diatomite of cycle UA28, coinciding with a glacial isotope stage (Van der Laan et al. 2008). Here, R. clavigera co-occurs with C. leptoporus and C. pelagicus, forming an assemblage already recorded by Silva et al. (2008) in the present-day Lisbon bay. Both C. leptoporus gr. and C. pelagicus prefer cold-temperate water column and high to moderate nutrient availability (Cachão and Moita, 2000; Cachão et al., 2000; Ziveri et al., 2004; Triantaphyllou et al., 2009; Okada and MacIntyre, 1979; Giraudeau et al., 1993; Giraudeau and Rogers, 1994 Winter et al., 1994; Negri et al., 1999a). It appears that the increase in abundance of the genus Rhabdosphaera can be explained by opportunistic behaviour at the end of the spring bloom when nutrient levels start to become impoverished. 
Rhabdosphaera clavigera is a minor component of the Messinian CN assemblage (Flores et al., 2005; Lozar et al., 2018; Lozar \& Negri, 2019; this study) that rarely exceed $10 \%$ of the total assemblage. The low $R$. clavigera abundance could be the result of some seasonal bloom, occurred when the spring temperature are high enough, runoff is low and nutrients are depleted in the upper water column. These conditions were seldom achieved during the deposition of the Upper Abad when the continental run-off was low during insolation maxima, or the spring temperatures were high enough during insolation minima.

\section{Helicosphaera carteri}

Helicosphaera carteri is an extant species that has been documented in mesotrophic/eutrophic, hyposaline and turbid waters (Giraudeau et al., 1992; Ziveri et al., 2004) and estuarine environments (Cachao et al., 2002). Its presence in the Black Sea is a further evidence of the capability to withstand salinity fluctuations. H. carteri also proliferates in the mid photic zone (Corselli et al., 2002; Crudeli et al., 2006) and has a preference for warm waters (McIntyre and Bé 1967; Brand 1994; Ziveri et al., 2004). Generally, in the Sorbas basin, $H$. carteri maxima in abundance are cyclically reached close, or in, the diatomite. Our data also reveal that $H$. carteri abundance acme occurs between UA29 and UA30, concurrently with a pronounced $\mathrm{Ba} / \mathrm{Ca}$ peak. These finding further indicate the ability of this species to tolerate salinity fluctuation (or reduction in the water transparency) due to the increased continental run-off in a mesotrophic environment.

\subsection{Factors controlling the sapropels deposition in the Sorbas Basin}

According to Sierro et al. (2003) the trigger for the sapropelitic deposition was the buoyancy gain of the surface water that promoted density stratification of the water column and anoxic condition at the sea floor. This mechanism was strengthened by the still relatively high productivity, which started during the deposition of the diatomite/upper marls and favoured the accumulation of organic matter at the sea floor (Sierro et al., 2003). This interpretation is based on the observation of the foraminifers distribution and their stable isotope signature. The new and extended $\mathrm{CN}$ data add new insights and contribute to better understand the mechanism of Messinian sapropel formation and its evolution towards the MSC onset.

The $\mathrm{CN}$ assemblages recorded at the transition from upper marls to sapropel and in the basal portion of the sapropel is dominated by $R$. minuta, $U$. rotula and $C$. leptoporus gr. Reticulofenestra minuta reflects high nutrient availability in the upper water column (Flores et al., 1995, 2000; Takahashi and Okada, 2000;Wade \& Bown, 2006; Imai et al., 2013, 2015, 2017; Auer et al., 2014; Athanasiou et al., 2015) as also highlighted by $U$. rotula (see 4.1 ). In our results, $C$. leptoporus gr. specimens mainly belong to the large morphotype, 
which proliferate today in mesotrophic environments (Ziveri et al., 2004). At the same time, the transition to the sapropel is also characterized by the presence of cold/eutrophic planktic foraminifers, such as $T$. quinqueloba/multiloba (above UA20; Sierro et al., 2003) and G. bulloides (below UA16). Benthic foraminifers are commonly dominated by high nutrient/low oxygen taxa from ca. 6.4 Ma onward (Bulimina gr., Bolivina gr. and Uvigerina/Rectouvigerina) (Sierro et al., 2003). Their maximum abundance is cyclically reached in the upper-marls, followed by a sudden drop at the sapropel inception. At the sapropel base the concomitance of high productivity at the sea surface, disappearance of benthic foraminifera and preservation of organic matter strongly suggests that the increasing export of organic carbon to the sea floor exceeded the threshold leading to oxygen deficiency. Moreover, oligotrophy and stratification proxies are commonly lacking at the sapropel inception throughout the UA. Consequently, the anoxic conditions reached at the sea floor were more likely related to the huge oxygen consumption of the organic matter at the sea bottom rather than to the stagnation of the basin, similarly to what happens today in the Oxygen Minimum Zone (Schimmelmann et al., 2016).

Evidences of stratification and DCM productivity are provided by Sphenolitus gr. high abundance in concomitance with surface oligotrophic planktic foraminifera (e.g. O. universa) in the middle-upper sapropel partition, where $\delta^{18} \mathrm{O}$ indicates a marked increase in the freshwater input (Sierro et al., 2003; Perez-Folgado et al., 2003, Reghizzi et al., 2017). With the establishment of predominantly stratified conditions, promoted by increasing runoff at time of maximum insolation (Sierro et al., 2003), most of the productivity shifted down to the DCM. The establishment of a DCM is a common feature characterizing the water column structure during Pleistocene sapropel deposition (Kemp \& Villareal, 2013; Rholing et al., 2015 and references therein). The primary production in the DCM is mainly a new production which greatly enhances the export of organic matter from the photic zone when the water column is stratified and the surface layer is depleted in nutrients (Legendre \& Le Fevre, 1989; Eppley, 1989). Among other things (sinking speed, coating, sorption onto mineral particles, redox condition, microbial consumption; Hedge \& Keil, 1995; Keil \& Mayer, 2004; Burdige, 2007; Keil, 2017), the efficiency of organic carbon export also depends on the depth of the sea floor with respect to the (photic zone) depth at which most of the productivity is generated. We speculate that the development of a DCM permits an efficient transfer of the sinking organic carbon to the sea floor, also because the organic carbon does not flow throughout the photic zone, where the organic matter consumption is more effective (Neuer et al., 2002; De La Rocha \& Passow, 2007). This mechanism is further enhanced when it occurs in a shallow environment like the Sorbas Basin, where benthic foraminifers and field observation suggest an evolution of the paleodepth from a fairly deep $(1100 \mathrm{~m})$ at the LU/UA transition to a shelf depth (ca. 150m) prior the MSC onset (Dronkert, 1976; Troelstra et al., 1989; van de Poel et al., 1992; Baggley, 2000; Clauzon et al., 2015; Modestou et al., 2015). 
Among DCM proxies, the absence of the DCM dweller Neogloboquadrinids, in concomitance with Sphenolithus gr., could be the result of different temperature preferences, because the living descendant of the Messinian Neogloboquadrinids proliferate today in the Mediterranean when winter temperatures are below $14^{\circ} \mathrm{C}$ (Kallel et al., 1997; Sierro et al., 2003). This is evident in the the sapropel of cycle UA32, which corresponds to a relatively low summer insolation maxima at $65^{\circ} \mathrm{N}$ (Laskar et al., 2004) compared to other cycles, allowing the Neogloboquadrinids to be present in high abundance (Sierro et al., 2003) and suppressing the Sphenolithus gr. abundance. Nevertheless, a good correlation exists between the Sphenolithus gr. and the Neogloboquadrinids by comparison of our results with the one provided by Sierro et al. (2003) (UA25, UA28 and UA33 lower marls). We argue that, while stratification increased during the middle upper part of the sapropel formation, productivity, in part transferred to the lower photic zone, remained an important factor leading to the organic matter preservation at the sea floor. Overall, the fossil assemblage reflects high productivity and organic carbon export at the sapropel inception (anoxia triggering factor), and the presence of stratification and a DCM in the upper part of the sapropel (anoxia maintaining factor). Deviations from the pattern above described are only observed in cycles UA25 and UA30, where Sphenolitus gr. are present already from the base of the sapropel, like in the UA5-UA8 interval (Flores et al., 2005). Planktic foraminifera are in line with these deviations; in fact, Globigerinoides sacculifer and $O$. universa are dominant (>80\%) in UA25 and UA30 sapropel base, respectively, indicating a well-established stratification with oligotrophic and warm surface waters (Sierro et al., 2003).

\subsection{Factors controlling the diatomite deposition in the Sorbas Basin}

The precessional quadripartite cycle of the pre-evaporitic Sorbas Basin represents a general deviation from the recurrent tripartite "Tripoli" precessional cycle outcropping in Sicily and Gavdos (Blanc-Valleron et al., 2002; Pèrez-Folgado et al., 2003). Basically, what differentiates the Sorbas Basin is the presence of the lower marls sandwiched between the sapropel and the diatomite. The fossil assemblage recorded in the lower marls is similar to that of the upper part of the sapropel, except for the presence of Neogloboquadrinids and benthic foraminifers. The $\mathrm{Ba} / \mathrm{Ca}$ values are cyclically slightly higher in the lower marls suggesting an enhanced freshwater input. All the proxies (oligotrophic planktic foraminifers, Sphenolithus gr., the $\delta^{18} \mathrm{O}$ and the Neogloboquadrinids) still point to strong stratification of the water column, with oligotrophic condition at the surface and the presence of a pronounced DCM during the lower marl deposition (Fig. 8). Notwithstanding, the return of benthic foraminifers in the lower marls (Sierro et al., 2003) is a clear signal of an oxygenation recovery at the sea floor. Rather than a come-back of mixing process that deliver oxygen at the sea bottom, it could be inferred that at this time a further shoaling of the nutricline occurred, as a result of the continued and enhanced riverine input started during the upper part of the sapropels, as also suggested by Sierro et al. (2003). The shoaling of the nutricline may result in an 
increased distance between the DCM and the sea floor, increasing the remineralisation of the organic matter during its sink trough the photic zone and suppressing the export flux at the sea floor, responsible for the anoxic condition.

The diatomites are generally characterized by the presence of $H$. carteri, C. pelagicus and $R$. pseudoumbilicus gr. among the $\mathrm{CN}$, and both cold/eutrophic and warm/oligotrophic planktic foraminifers (decreasing warm/oligotrophic over cold/eutrophic ratio; Sierro et al., 2003). The ecological requirement for $H$. carteri are discussed above (see 4.1); C. pelagicus is referred as a cold species with the preference of high nutrient availability (Negri et al., 1999a, b; Ziveri et al., 2004), probably provided by upwelling (Cachão and Moita, 2000; Giraudeau et al., 1993; Giraudeau and Rogers, 1994), although some authors attribute to C. pelagicus the capability to proliferate in a wide range of salinity (from 26.9 to $36 \%$ ) (Silva et al., 2008). Reticulofenestra pseudoumbilicus is referred to prefer high nutrient availability, with no particular preferences for water temperature (Lohmann and Carlson, 1981). The coexistence of cold/eutrophic, warm/oligotrophic and fresh water sensitive specimens may indicate that the diatomite deposition was characterized by strong seasonality, with more oligotrophic surface condition associated with a DCM during summer, and more eutrophic surface condition during winter/spring. A strong seasonality during the diatomite deposition is further indicated by the presence of Thalassionema and Rhizosolenia (PèrezFolgado et al., 2003) among the diatoms. In fact, Thalassionema is generally associated with surface productivity (McKenzie et al., 1979; Moissette and Saint Martin, 1992), conditions probably occurred during winter, and Rhizosolenia is generally referred as a DCM inhabitant (Margalef, 1978; Kemp and Villareal, 2013), condition probably occurred during summer.

According to Filippelli et al. (2003) siliceous productivity was triggered by a mechanism of enrichment in phosphorous, called sediment-nutrient-oxygen feedback (SNO Effect), which acted within the Sorbas Basin at the precessional scale. The authors suggest that during the sapropel deposition, the bottom water stagnation caused the build-up of phosphorous in the surface sediments, below the photic zone. This trapped the phosphorous reservoir below the pycnocline; the phosphorous was then injected back in the photic zone at the recovery of the water mixing during cold phase, resulting in an increased biosiliceous productivity and the consequent diatomite deposition. Supporting this scenario, we also claim that the dissolved silica is the main limiting nutrient for biosiliceous productivity (Ragueneau et al., 2000), and the preservation of the diatom frustules is strongly related to the dissolved silica content in the water column and in the sediments (Pellegrino et al., 2018). The dissolved silica in the ocean, like phosphorous, is mainly provided by continental run-off (Paytan and Karen McLaughlin, 2007; Treguer \& De La Rocha, 2013; Pellegrino et al., 2018) and it can be associated with the phosphorous SNO effect as well, because the silica content in the water column increases with water depth. The dissolved silica and phosphorous were mainly provided by the rivers during the upper part of the sapropel and lower marl deposition, remaining trapped below the photic zone because of the stratification that occurred at this time. When the temperature 
started to gradually decrease, promoting water mixing and the disruption of the stratification, the nutrients were distributed in the photic zone stimulating biosiliceous productivity. Moreover, the same mechanism suggested by Filippelli et al. (2003) at the precessional scale, may be responsible for the cyclical dissolved silica and phosphorous enrichment in the photic zone during an annual cycle: during spring the nutrient were provided by run-off and remained trapped below the photic zone during summer stratification, then the stratification break during autumn/winter distributed the nutrients in the photic zone. The break of the stratification that occur during late autumn, could promote a huge diatoms flux at the sea bottom (i.e. fall dump, according to Kemp et al. 2000). The rapid accumulation of diatoms at the sea floor was responsible of the temporary oversaturation of dissolved silica, promoting diatom frustules preservation. The Neogloboquadrinids are phytoplankton grazers which feeds diatoms that are adapted to exploit the DCM (Hemleben et al., 1989; Sierro et al., 2003). The concomitant presence of scattered diatom frustules and the Neogloboquadrinids during the lower marls deposition, indicate that the diatoms were present also during this interval, but the diatom flux at the sea floor was not sufficient to sustain the dissolved silica oversaturation, responsible for the diatoms preservation.

The strong seasonal signal derived by the microfossil assemblages which characterizes the diatomites suggests that runoff was still important to sustain siliceous productivity by replacing the fraction of silica buried in the sediments.

Above the diatomites, the upper marls are characterized by high productivity mainly confined in the surface water expressed by the fossil assemblage (see 4.2). Thus, the decline of the siliceous productivity (below the threshold of silica preservation) was related to the combination of the depletion of the silica and phosphorous deep reservoir (by means of the SNO effect) and the decreased runoff contribution (Sierro et al., 2003). The latter was a consequence of the decreasing insolation index leading to drier and colder conditions.

\subsection{The sapropel UA34 case}

Differently from cycles UA1 to UA33, the cycle UA34 does not show the quadripartite pattern, as it is mainly made up of dark, organic-rich marls (sapropel-like), intercalated with three indurated layers (see chapter 2.2). Increases of $R$. pseudoumbilicus gr. and $C$. pelagicus were recorded below the second limestone layer in organic-rich layers. In our results $R$. pseudoumbilicus gr. and C. pelagicus maxima abundance are recorded during diatomite deposition, consequently we suggest that the $R$. pseudoumbilicus gr. and $C$. pelagicus increases in the cycle UA34, in the poorly or well laminated sapropels below the second limestone layer, indicate the transition from insolation maximum to minimum. The transition from insolation maximum to insolation minimum is further indicated by diatoms presence, which frequently occurred at this level (Fig.4). We suggest that, at the time just before the MSC onset, the ongoing basin 
restriction promoted an increase in the marine productivity resulting in an enhanced export of the organic matter to the sea bottom; this in turn led to anoxic bottom conditions, without the contribution of the stagnation of the deep water. This mechanism resulted in a constant accumulation of organic-rich sediments and the obliteration of the cyclic pattern observed in the older UA cycles.

This represents another clue indicating that the stagnation of the basin played a secondary role in the sapropel deposition in the shallow Sorbas Basin, which is best explained by oxygen consumption at the sea bottom due to the high productivity and high organic matter export from the photic zone.

\subsection{The MSC-CN bioevent record in the Western Mediterranean}

Basically, the MSC bioevent was recorded in all land sections reporting a CN abundance record. The MSC bioevent consists of a succession of abundance peaks of the species S. abies, followed or accompanied by $H$. carteri, $U$. rotula and R. clavigera. This peculiar succession of bioevents is recorded in the Perales section in the cycle UA34, reinforcing the idea that the same paleoenvironmental change took place in the whole Mediterranean approximately at the MSC onset. Based on the reported widespread occurrence, we confirm that the MSC bioevent is a good proxy of the MSC onset occurrence (Lozar et al., 2018) and it also represents a reliable tool for deciphering the environmental changes characterizing the onset of this basinwide event. Information regarding the MSC-CN record across the Mediterranean and its detailed description are collected in Lozar and Negri (2019).

\subsection{Paleoenvironmental reconstruction during the MSC bioevent}

Prior to the MSC, the Mediterranean was affected by a progressive restriction of the marine connections with the Atlantic Ocean, commonly related to tectonic uplift processes in the gateway area (Duggen et al., 2003; Garcia-Castellanos and Villaseñor, 2011). The first evidence of significant restriction in the Mediterranean-Atlantic exchange was recorded by a reduction of deep-water ventilation all over the Mediterranean at 7.15 Ma, after the Tortonian-Messinian boundary (Kouwenhoven et al., 1999, 2003). This event is also associated with the increased deposition of diatom-rich sediments (Tripoli Formation, Sicily) or opal-rich deposits (Upper Abad, Spain) observed between 7.15 Ma and 6.7 Ma throughout the Mediterranean. The widespread precipitation of authigenic calcite, dolomite and/or aragonite between 6.3 and 5.97 Ma, immediately prior to the MSC onset, is another response to ongoing restriction (Roveri et al., 2014). This restriction in the Sorbas Basin resulted in a shallowing of the basin (Dronkert et al., 1976; Troelstra et al., 1980; van de Poel et al., 1992; Baggley, 2000; Clauzon et al., 2015, Modestou et al., 2015). An abrupt shoaling of the water depth (from 500-300 to 200m) is recorded in Pissouri section (Cyprus; Kouwhenoven et al., 2006) during the MSC bioevent, found just below the "barre jaune" that precedes the evaporites deposition. In Banengo, Moncalvo and Pollenzo sections (Italy; Lozar et al., 2018) only few 
precessional cycles (from 2 to 4 ) are present below the MSC bioevent, complicating the recognition of shoaling features. However, in these sections, the MSC bioevent is accompanied by the presence of benthic foraminifers indicating shallow water (Banengo and Moncalvo; Lozar et al., 2018) or deep outer neritic to bathyal environment (Pollenzo section; Lozar et al., 2018).

As described above, the cycle UA34 of the Sorbas Basin represents the pre-evaporitic restriction acme. In this framework the MSC biovent, found approximately at the MSC onset in the whole Mediterranean, is somehow related to this restriction effect. The acme of the pre-evaporitic basin restriction had the effect of modifying the basin susceptibility to the fresh water and nutrient input, due to decreased dilution caused by the reduction of the entering Atlantic water in the Mediterranean. This ultimately had the effect of amplifying the (paleo) ecological signal recorded in the sediment.

Approximately at the MSC onset, during the insolation maximum, the basin restriction in the whole Mediterranean, continuously affected by continental run-off, may have resulted in a reduced surface water buoyancy loss. The density differences between surface and intermediate waters is a recurrent feature reported before and during sapropel formation (Rohling et al., 2015 and references therein) and is thought to trigger the shoaling of the intermediate water toward the base of the photic zone, promoting new nutrient advection and fuelling the DCM (Rohling \& Gieskes. 1989; Castradori et al., 1993; Rohling et al., 1994; Corselli et al., 2002). These conditions could have triggered the Sphenolithus gr. peak during the MSC$\mathrm{CN}$ bioevent in the whole Mediterranean. When the protracted continental run-off further decreased the surface buoyancy loss and triggered a further shoaling of the DCM, Sphenolithus gr. started to decrease. The protracted continental run-off also resulted in an increased surface salinity fluctuation, turbidity and high nutrient supply, limiting the light penetration in the photic zone and constraining the productivity in the middle-upper photic zone. These conditions led $U$. rotula and $H$. carteri to flourish. Seasonally, when the spring temperatures were high enough and nutrients started to be depleted or confined to the upper photic zone, R. clavigera peaked.

Above the MSC bioevent, the CN continue to be present for one precessional cycle in Tokhni section (Cyprus; Gennari et al., 2018), for two precessional cycles in Pollenzo section (Italy; Lozar et al., 2018), for ten precessional cycles in Fanantello section (Italy, Manzi et al., 2007); in Moncalvo (Italy; Lozar et al., 2018) only diatoms are recorded in the cycles above the MSC bioevent. In all of these sections the evaporite deposition is delayed and replaced by organic-rich shales and carbonate. Overall, the fossil assemblage following the MSC bioevent reflects eutrophic conditions (Lozar et al., 2018; Gennari et al., 2018), resulting from the gateway restriction amplifying the continental run-off delivery of nutrients into the receiving basin. We suggest that the widespread record of the MSC-CN bioevent in the Mediterranean is the fossil signal marking the last step of the restriction straddling the MSC onset, resulting in a widespread increase of marine productivity due to the overwhelming influence of the continental run-off to the basin. 


\section{CONCLUSIONS}

$\mathrm{CN}$ and geochemical analyses on $\mathrm{O}$. universa tests were performed on the sediments spanning the MSC onset in the Sorbas Basin, adding new insight on the paleoenvironmental condition triggering the cyclical deposition of the lithological quadripartite cycle and on the MSC onset.

Some important differences emerged between the most recent Holocene/Pleistocene sapropels deposited in deep water setting and the shallow Sorbas Basin sapropels. The formers were commonly characterized by a stratified water column at the onset of the saropelitic episode; the latter by high organic carbon export at the sapropel inception and by a DCM development in the middle-upper part of the sapropel. These differences challenged the view of a single mechanism as a trigger for the cyclical sapropel deposition throughout the Neogene and Quaternary Periods. Whilst the disruption of deep and intermediate water circulation can still be considered the driving cause for deep water Plio-Pleiostecene sapropel formation (Rohling et al., 2015), we point for productivity processes as more relevant in marginal and restricted basins, like the Sorbas Basin.

The diatomite preservation in the geological record is related to conditions of exceptional high dissolved silica in the water column, that is mainly provided by the rivers. In the Sorbas Basin the increased freshwater input, occurred during the upper part of the sapropel and the lower marl deposition, generated a deep reservoir of nutrients (dissolved silica and phosphorous) that were injected in the photic zone when the decrease in temperature promoted the disruption of the stratification. This mechanism promoted a huge diatoms proliferation and the consequent diatomite deposition. When the deep reservoir of dissolved silica was exhausted and was not replaced by continental run-off, bioturbated marl were deposited again at the top of the precessional cycle.

In the last pre-evaporitic cycle (UA34), C. pelagicus and R. pseoudoumbilicus gr. increase their abundance indicating a temperature decrease, a condition matching the passage from insolation maximum to insolation minimum. At this time, the deposition of sapropel-like layers further suggests that the deposition of organic-rich sediments does not necessarily require deep water stagnation.

The cycle UA34 also records a precise sequence of CN peaks in abundance (MSC-CN bioevent); this event was previously reported in the Messinian sections straddling the MSC onset in the Northern and Eastern Mediterranean. The MSC-CN bioevent is comprised by a succession of peak abundances of Sphenolithus gr., followed or accompanied by U. rotula, $H$. carteri and R. clavigera, and represents a useful tool to approximate the MSC onset. This peculiar and widespread fossil signal is the result of the restriction affecting the Atlantic gateway, that ultimately amplified the nutrients and continental run-off susceptibility of the Mediterranean Basin, due to the decreased dilution effect of the Atlantic water in the recipient basin. The obliteration of the lithologically quadripartite cycle affecting the last pre-evaporitic cycle is also related to this restriction pulse. Overall, in both Eastern and Western Mediterranean the fossil signal above 
the MSC-CN bioevent reflects the increase in marine productivity induced by the basin restriction that triggered the evaporitic phase.

Appendix A: Taxonomic appendix:

Amaurolithus delicatus (Gartner and Bukry, 1975)

Amaurolithus primus (Bukry and Percival, 1971)

Braarudosphaera bigelowii (Gran \& Braarud 1935)

Calcidiscus leptoporus (Murray and Blackman, 1898)

Calciosolenia fossilis (Deflandre in Deflandre \& Fert 1954)

Coccolithus pelagicus (Wallich, 1877)

Discoaster brouweri (Tan, 1927)

Discoaster pentaradiatus (Tan, 1927)

Discoaster variabilis (Martini and Bramlette, 1963)

Discosphaera tubifera (Murray \& Blackman 1898)

Helicosphaera carteri (Wallich, 1877)

Pontosphaera discopora (Schiller, 1925)

Pontosphaera japonica (Takayama 1967)

Pontosphaera multipora (Roth, 1970)

Reticulofenestra antarctica (Haq, 1976)

Reticulofenestra haqii (Backman, 1978)

Reticulofenestra minuta (Roth, 1970)

Reticulofenestra pseudoumbilicus (Gartner, 1967).

Reticulofenestra rotaria (Theodoridis, 1984)

Rhabdosphaera clavigera (Murray and Blackman, 1898)

Sphenolithus abies (Deflandre and Fert, 1954)

Sphenolithus moriformis (Brönnimann \& Stradner, 1960)

Syracosphaera pulchra (Lohmann, 1902)

Umbilicosphaera rotula (Kkamptner, 1956)

Umbilicosphaera jafari (Mu“ Iler, 1974)

Thoracosphaera heimii (Lohmann 1920)

\section{Rerefences}

Alldredge, A. L., Gotschalk, C. C., 1988. Direct observations of the mass flocculation of diatom blooms: characteristics, settling velocities and formation of diatom aggregates. Deep Sea Res. 36, 159-171 
Alves, T.D., Cooper, M.K.E, Rios-Netto, A.M., 2016.Paleogene-Neogene calcareous nannofossil biostratigraphy and paleoecological inferences from northern Campos Basin, Brazil (well Campos-01). Journal of South American Earth Sciences. 71, 143-160.

Anand, P., Elderfield, H., Conte, M.H., 2003. Calibration of Mg/Ca thermometry in planktonic foraminifera from a sediment trap time series. Paleoceanography 18, 1050.

Athanasiou, M., Triantaphyllou, M.V., Dimiza, M. D., Gogou, A., Theodorou, G., 2015. Zanclean/Piacenzian transition on Cyprus (SE Mediterranean): calcareous nannofossil evidence of sapropel formation. Geo-Mar Lett 35, 367-385.

Aubry, M.-P., 1992. Late Paleogene calcareous nannoplankton evolution: a tale of climatic deterioration. In: Prothero, D.R., Berggren, W.A. (Eds.), Eocene-Oligocene Climatic and Biotic Evolution. Princeton University Press, New Jersey 272-208.

Auer, G., Piller, W.E., Mathias Harzhauser, M., 2014. High-resolution calcareous nannoplankton palaeoecology as a proxy for small-scale environmental changes in the Early Miocene. Marine Micropaleontology 111, 53-65.

Baggley, K. A. 2000. The late Tortonian-early Messinian foraminiferal record of the Abad Member (Turre formation), Sorbas Basin, Almería, south-east Spain, Palaeontology 43, 1069-111.

Barker, S., Greaves, M., Elderfield, H., 2003. A study of cleaning procedures used for foraminiferal $\mathrm{Mg} / \mathrm{Ca}$ paleothermometry. Geochem. Geophys. Geosyst. 4, 8407.

Barker, S., Cacho, I., Benway, H., Tachikawa, K., 2005. Planktonic foraminiferal $\mathrm{Mg} / \mathrm{Ca}$ as a proxy for past oceanic temperatures: a methodological overview and data compilation for the Last Glacial Maximum. Quat. Sci. Rev. 24, 821-834.

Blanc-Valleron, M.M., Pierre, C., Caulet, J.P., Caruso, A., Rouchy, J. M., Cespuglio, G., Sprovieri, R., Pestrea, S., Di Stefano, E., 2002. Sedimentary, stable isotope and micropaleontological records of paleoceanographic change in the Messinian Tripoli Formation (Sicily, Italy). Palaeogeography, Palaeoclimatology, Palaeoecology 185, 255-286.

Boyle, E.A., Keigwin, L.D., 1985. Comparison of Atlantic and Pacific paleochemical records for the last 215,000 years: changes in deep ocean circulation and chemical inventories. Earth Planet. Sci. Lett. 76, 135150.

Braga, J.C.,Martín, J.M., Riding, R., Aguirre, J., Sanchez-Almazo, I.M., Dinares-Turell, J., 2006. Testing models for the Messinian salinity crisis: the Messinian record in Almería, SE Spain. Sedimentary Geology 188-189, 131-154.

Brand, L.E., 1994. Physiological ecology of marine coccolithophores. In: Winter, A., Siesser, A. (Eds.), Coccolithophores. Cambridge University Press, Cambridge, 39- 49.

Burdige DJ. 2007. Preservation of organic matter in marine sediments: controls, mechanisms, and an imbalance in sediment organic carbon budgets? Chem. Rev. 107, 467-85

Cachaõ, M., Oliveira, A., Vitorino, J., 2000.Subtropical winter guests, offshore Portugal. Journal of Nannoplankton Research 22, 19-26. 
Cachaõ, M., Drago, T., Silva, A.D., Moita, T., Oliveira, A., Naughton, F., 2002. The secret (estuarine?) life of Helicosphaera carteri: preliminary results. Journal of Nannoplankton Research 24, 76-77.

Castradori, D., 1993. Calcareous nannofossils and the origin of eastern Mediterranean sapropels. Paleoceanography 8, 459-471.

Castradori, D., 1998. Calcareous nannofossils in the basal Zanclean of the eastern Mediterranean Sea: remarks on paleoceanography and sapropel formation. Proc. Ocean Drill. Program Sci. Results 160, 113123.

Clauzon, G., Suc, J.P., Do Couto, D., Jouannic, G., Melinte-Dobrinescu, M.C., Jolivet, L., Martinell, J., 2015. New insights on the Sorbas Basin (SE Spain): the onshore reference of the Messinian salinity crisis Mar. Pet. Geol. 66, 71-100.

Corselli, C., Principato, M.S., Maffioli, P., Crudelli, D., 2002. Changes in planktonic assemblages during sapropel S5 deposition: evidence from Urania Basin area, eastern Mediterranean. Paleoceanography 17.

Crudeli, D., a, Young, J.R., Erba, E., Geisen, M., Ziveri, P., de Lange, G.J., P. Slomp, C.P., 2006. Associations from the Mediterranean (Holocene-late Pleistocene):Evaluation of carbonate diagenesis and palaeoecological-palaeocenographic implications. Palaeogeography, Palaeoclimatology, Palaeoecology 237, $191-224$.

Dela Pierre, F., Clari, P., Natalicchio, M., Ferrando, S., Giustetto, R., Lozar, F., Lugli, S., Manzi, V., Roveri, M., Violanti, D., 2014. Flocculent layers and bacterial mats in the mudstone interbeds of the primary lower Gypsum unit (Tertiary Piedmont basin, NW Italy): Archives of palaeoenvironmental changes during the Messinian salinity crisis. Mar. Geol. 355, 71-87.

De La Rocha, C.L., Passow, U., 2007. Factors influencing the sinking of POC and the efficiency of the biological carbon pump. Deep-Sea Res. II 54, 639-58.

Dronkert, H., 1976. Late Miocene evaporites in the Sorbas Basin and adjoining areas, Mem. Soc. Geol. Italy, 341-361.

Elderfield, H., Ganssen, G., 2000. Past temperature and $\delta 180$ of surface ocean waters inferred from foraminiferal $\mathrm{Mg} / \mathrm{Ca}$ ratios. Nature 405, 442-44.

Erez, J., 2003. The source of ions for biomineralization in foraminifera and their implications for paleoceanographic proxies. Rev. Mineralog. Geochem. 54, 115-149.

Flecker, R., Krijgsman, W., Capella, W., de Castro Martins, C., Dmitrieva, E., Mayser, J. P., Marzocchi, A., Modestou, S., Ochoa, D., Simon, D., Tulbure, M., van den Berg, B., van der Schee, M., de Lange, G., Ellam, R., GoversR., Gutjahr, M., Hilgen, F., Kouwenhoven, T., Lofi, J., Meijer, P., Sierro, F. J., Bachiri, N., Barhoun, N., Alami, A. C., Chacon, B., Flores, J. A., Gregory, J., Howard, J., Lunt, D., Ochoa, M., Pancost, R., Vincent, S., Yousfi, M. Z., 2015. Evolution of the Late Miocene Mediterranean-Atlantic gateways and their impact on regionaland global environmental change. Earth-Science Reviews 150, 365-392.

Flores, J.A., Sierro, F.J., Raffi, I., 1995. Evolution of the calcareous nannofossil assemblage as a response to the paleoceanographic changes in the eastern equatorial Pacific Ocean from 4 to $2 \mathrm{Ma}$ (Leg 138, Sites 849 and 852). Proc. Ocean Drill. Program Sci. Results 138, 163- 176. 
Flores, J. A., Sierro, F. J., Filippelli, G. M., Barcena, M. A., Pèrez- Folgado, M., Vazquez, A., Utrilla, R., 2005. Surface water dynamics and phytoplankton communities during deposition of cyclic late Messinian sapropel sequences in the western Mediterranean. Marine Micropaleontology 56, 50-79.

Fortuin, A.R., Krijgsman, W., Hilgen, F.J., Sierro, F.J., 2000. Late Miocene Mediterranean desiccation: topography and significance of the "Salinity Crisis" erosion surface onland in southeast Spain: comment. Sedimentary Geology 133, 167-174.

Gennari, R., Lozar, F., Turco, E., Dela Pierre, F., Manzi, V., Natalicchio, M., Lugli, S., Roveri, M., Schreiber, B.C., Taviani, M., 2018. Integrated stratigraphy and paleoceanographic evolution of the pre-evaporitic phase of the Messinian salinity crisis in the Eastern Mediterranean as recorded in the Tokhni section (Cyprus island). Newsl. Stratigr. 51, 33-55.

Gibbs, S., Shackleton, N., Young, J. R., 2004. Orbitally forced climate signals in mid-Pliocene nannofossil assemblages. Marine Micropaleontology 51, 39-56.

Giraudeau, J., 1992. Distribution of recent nannofossils beneath the Benguela system: southwest African continental margin. Marine Geology 108, 219-237.

Griffin, D.L., 2002. Aridity and humidity: two aspects of the late Miocene climate of North Africa and the Mediterranean. Palaeogeogr. Palaeoclimatol. Palaeoecol. 182, 65-91.

Jorissen, F.J., De Stigter, H.C., Widmark, J.G.V., 1995. A conceptual model explaining benthic foraminiferal microhabitats. Mar. Micropaleontol. 26, 3-15.

Kallel, N., Paterne, M., Labeyrie, L.D., Duplessy, J.C. and Arnold, M., 1997. Temperature and salinity records of the Tyrrhenian sea during the last 18000 years. Palaeogeography, Palaeoclimatology, Palaeoecology, 135, 97-108.

Keil, R., 2017. Anthropogenic Forcing of Carbonate and Organic Carbon Preservation in Marine Sediments Annu. Rev. Mar. Sci.. 9, 151-72.

Kemp, A.E.S., Pike, J., Pearce, R.B., Lange, C.B., 2000. The "Fall dump" - a new perspective on the role of a "shade flora" in the annual cycle of diatom production and export flux. Deep-Sea Res. Pt. II 47, 2129-2154.

Kemp, A.E.S., Villareal, T.A., 2013. High diatom production and export in stratified waters-A potential negative feedback to global warming. Prog. Oceanogr. 119, 4-23.

Kennett, J. P., Srinivasan, M. S., 1983. Neogene Planktonic Foraminifera - A phylogenetic atlas. Hutchinson Ross Publishing Company, Stroudsburg, Pennsylvania, U.S.A. 265.

Krijgsman, W., F. J. Hilgen, I. Raffi, and F. J. Sierro (1999), Chronology, causes and progression of the Messinian salinity crisis. Nature 400, 652-655.

Kouwenhoven, T.J., Seidenkrantz, M.S., van der Zwaan, G.J., 1999. Deep-water changes: the near synchronous disappearance of a group of benthic foraminifera from the Late Miocene Mediterranean. Palaeogeogr. Palaeoclimatol. Palaeoecol. 152, 259-281.

Kouwenhoven, T. J., Hilgen, F. J. \& van der Zwaan, G. J., (2003). Late Tortonian-early Messinian stepwise disruption of the Mediterranean-Atlantic connections: constraints from benthic foraminiferal and geochemical data. Palaeogeography, Palaeoclimatology, Palaeoecology, 198, 303-319. 
Kouwenhoven, T.J., Morigi, C., Negri, A., Giunta, S., Krijgsman, W., Rouchy, J.M., 2006. Palaeoenvironmental evolution of the eastern Mediterranean during the Messinian: constraints from integrated microfossil data of the Pissouri Basin (Cyprus). Mar. Micropaleontol. 60, 17-44.

Haidar, A. T., Thierstein, H. R. (2001) Coccolithophore dynamics off Bermuda (N. Atlantic). Deep-Sea Res. II , 48, 1925-1956.

Hanor, J. S., Chan, L. H., 1977. Non-conservative behavior of barium during mixing of Mississippi River and Gulf of Mexico waters. Earth Planet. Sci. Lett.. 37, 242-250.

Hedges JI, Keil RG., 1995. Sedimentary organic-matter preservation: an assessment and speculative synthesis. Mar. Chem. 49, 81-115.

Hemleben, Ch., Spindler, M., Anderson, O.R., 1989. Modern Planktonic Foraminifera. Springer, New York, 363.

Hilgen, F. J., Krijgsman, W.,1999. Cyclostratigraphy and astrochronology of the Tripoli diatomite formation (pre-evaporite Messinian, Sicily, Italy), Terra Nova. 11, 16-22.

laccarino, S.M., Bertini, A., Di Stefano, A., Ferraro, L., Gennari, R., Grossi, F., Lirer, F., Manzi, V., Menichetti, E., Ricci Lucchi, M., Taviani, M., Sturiale, G., Angeletti, L., 2008. The Trave section (Monte dei Corvi, Ancona, Central Italy): an integrated paleontological study of the Messinian deposits. Stratigraphy 5, 281-306.

Imai, R., Sato, T., Iryu, Y., 2013. Chronological and paleoceanographic constraint of Miocene to Pliocene 'mud sea' in the Ryukyu Island (southwestern Japan) based on calcareous nannofossil assemblages. Island Arc 22, 522-537.

Imai, R., Farida, M., Sato, T., Iryu, Y., 2015. Evidence for ocean eutrophication in the northwestern Pacific and eastern Indian oceans during the Miocene to Pleistocene based on the nannofossil accumulation rate, Discoaster abundance, and coccolith size distribution of Reticulofenestra. Mar. Micropaleontol. 116, 15-27.

Imai, R., Sato, T., Iryu, Y., 2017. Calcareous nannofossil assemblages of the upper Miocene to Pliocene Shimajiri Group on Okinawa-jima, Ryukyu Islands, southwestern. Japan Journal of Asian Earth Sciences. 135, 16-24

Laskar, J., Robutel, P., Joutel, F., Gastineau, M., Correia, A. C. M., Levrard, B., 2004. A long-term numerical solution for the insolation quantities of the Earth. Astronomy and Astrophysics 428, 261-285.

Lea, D.W., Boyle, E.A., 1991. Barium in planktonic foraminifera. Geochimica et Cosmochimica Acta 55, 3321-3331.

Lea, D.W., Mashiotta, T.A., Spero, H.J., 1999. Controls on magnesium and strontium uptake in planktonic foraminifera determined by live culturing. Geochim. Cosmochim. Acta 63, 2369-2379.

Loeblich, A. R., Tappan, H. 1988. Foraminiferal genera and their classification. Van Nostrand Reinhold, New York, U.S.A. 1, 847-970.

Lozar, F., Violanti, D., Dela Pierre, F., Bernardi, E., Cavagna, S., Clari, P., Irace, A., Martinetto, E., Trenkwalder, S., 2010. Calcareous nannofossils and foraminifers herald the Messinian salinity crisis: the Pollenzo section (Alba, Cuneo; NW Italy). Geobios 43, 21-32. 
Lozar, F., Violanti, D., Bernardi, E., Dela Pierre, F., Natalicchio, M., 2018. Identifying the onset of the Messinian salinity crisis: a reassessment of the biochronostratigraphic tools (Piedmont Basin, NW Italy) Newsletters on Stratigraphy. 51/1, 11-31.

Lozar, F., Negri A., 2019. A review of basin-wide calcareous nannofossil bioevents in the Mediterranean at the onset of the Messinian salinity crisis Marine Micropaleontology. 151, 101752.

Malinverno, E., Ziveri, P., Corselli, C., 2003. Coccolithophorid distribution in the Ionian Sea and its relationship to eastern Mediterranean circulation during late fall to early winter 1997 journal of geophysical research. $108,8115$.

Manzi, V., Roveri, M., Gennari, R., Bertini, A., Biffi, U., Giunta, S., laccarino, S.M., Lanci, L., Lugli, S., Negri, A., Riva, A., Rossi, M.E., \& Taviani, M. (2007), The deep-water counterpart of the Messinian Lower Evaporites in the Apennine foredeep: the Fanantello section (Northern Apennines, Italy). Palaeogeogr. Palaeoclimatol. Palaeoecol., 251, 470-499.

Manzi, V., Gennari, R., Hilgen, F., Krijgsman, W., Lugli, S., Roveri, M., Sierro, F.J., 2013. Age refinement of the Messinian salinity crisis onset in the Mediterranean. Terra Nova 25, 315-322.

Manzi, V., Gennari, R., Lugli, S., Persico, D., Reghizzi, M., Roveri, M., Schreiber, C., Calvo, R., Gavrieli, I. \& Gvirtzman, Z., (2018). The onset of the Messinian salinity crisis in the deep Eastern Mediterranean basin. Terra Nova, 30, 189-198.

Martin, J.M., and Meybeck, M., 1979, Elemental mass-balance of material carried by major world rivers, Mar. Chem. 7, 173-206.

Martín, J. M., and Braga, J.C., 1994. Messinian events in the Sorbas Basin in southeastern Spain and their implications in the recent history of the Mediterranean. Sediment. Geol. 90, 257-268.

Mejía-Molina, A., Flores, J.-A., Torres, V., Sierro, F.J., 2010. Distribution of calcareous nannofossils in Upper Eocene-Upper Miocene deposits from Northern Colombia and the Caribbean sea Revista Española de Micropaleontología, 42, 279-300.

Milker, Y, Schmiedl, G., 2012. A taxonomic guide to modern benthic shelf foraminifera of the western Mediterranean Sea. Palaeontologia Electronica, 15, 1-134.

Modestou, S., Simon, D., Gutjahr, M., Marzocchi, A., Kowenhoven, T.J., Ellam, R.M., Flecker, R., 2017. Precessional variability of $87 \mathrm{Sr} / 86 \mathrm{Sr}$ in the late Miocene Sorbas Basin: an interdisciplinary study of drivers of interbasin exchange. Paleoceanography $32,531-552$.

Natalicchio M.,, Dela Pierre F., Birgel D., Brumsack H., Carnevale G., Gennari R., Gier S., Lozar F., Pellegrino L., Sabino M., Schnetger B., Peckmann J., 2019.Paleoenvironmental change in a precession-paced succession across the onset of the Messinian salinity crisis: Insight from element geochemistry and molecular fossils Palaeogeography, Palaeoclimatology, Palaeoecology 518, 45-61.

Negri, A., Capodonti, L., Keller, J., 1999a. Calcareous nannofossils, planktic foraminifers and oxygen isotope in the late Quaternary sapropels of the Ionian Sea. Mar. Geol. 151, 84-89.

Negri, A., Giunta, S., Hilgen, F.J., Krijgsman, W., Vai, G.B., 1999b. Calcareous nannofossil biostratigraphy of the $M$. del Casino section (northern Apenines, Italy) and paleoceanographic conditions at times of late Miocene sapropel formation. Mar. Micropaleontol. 36, 13-30. 
Neuer, S., Davenport, R., Freudenthal, T., Wefer, G., Llinàs, O., Rueda, M.-J., Steinberg, D.K., Karl, D.M., 2002. Differences in the biological carbon pump at three subtropical ocean sites. Geophysical Research Letters 29, 1985.

Okada, H., Mclntyre, A., 1979. Seasonal distribution of modern coccolithophorids in the Western North Atlantic Ocean. Marine Biology 54, 319-328.

Pèrez-Folgado, M., Sierro, F.J., Bàrcena, M.A., Flores, J.A., Vàzquez, A., Utrilla, R., Hilgen, F.J., Krijgsman, W., Filippelli, G.M., 2003. Western versus eastern Mediterranean paleoceanographic response to astronomical forcing: a high-resolution microplankton study of precession-controlled sedimentary cycles during the Messinian. Palaeogeogr. Palaeoclimatol. Palaeoecol. 190, 317-334.

Quinn, P., Saez, A.G., Baumann, K.-H., Steel, B.A., Sprengel, C., and Medlin, L.K., 2004. Coccolithophorid biodiversity: Evidence from the cosmopolitan species Calcidiscus leptoporus. In: H.R. Thierstein and J.R. Young, Eds., Coccolithophores - From molecular processes to global impact. Springer, 299-326.

Ragueneau, O., Tréguer, P., Leynaert, A., Anderson, R.F., Brzezinski, M.A., DeMaster, D.J., Dugdale, R.C., Dymond, J., François, R., Heinze, C., Maier-Reimer, E., Martin-Jézéquel, V., Nelson, D.M., Quéguiner, B., 2000. A review of the Si cycle in the modern ocean: recent progress and missing gaps in the application of biogenic opal as a paleoproductivity proxy. Glob. Planet. Change. 26 (4), 317-365.

Reghizzi, M., R. Gennari, E. Douville, S. Lugli, V. Manzi, P. Montagna,M. Roveri, F. J. Sierro, Taviani, M., 2017. Isotope stratigraphy (87Sr/86Sr, $8180, \delta 13 \mathrm{C}$ ) of the Sorbas basin (Betic Cordillera, Spain): Paleoceanographic evolution across the onset of the Messinian salinity crisis, Palaeogeogr. Palaeoclimatol. Palaeoecol. 469, 60-73.

Rodríguez-Tovar, F.J., Sa'nchez-Almazo, I., Pardo-Igu'zquiza, E., Braga, J.C., Martìn, J.M., 2013. Incidence of obliquity and precessionforced Milankovitch cycles in the western Mediterranean: early Messinian sedimentation in the Sorbas Basin (Almerı'a, southern Spain). Int. J. Earth Sci. 102, 1735-1755.

Rohling, E.J., Gieskes, W.W.C., 1989. Late Quaternary changes in Mediterranean Intermediate Water density and formation rate. Paleoceanography 4, 531-545.

Rohling, E.J., 1994. Review and new aspects concerning the formation of Mediterranean sapropels. Mar. Geol. 122, 1-28.

Rohling, E. J., G. Marino, and K. M. Grant (2015), Mediterranean climate and oceanography, and the periodic development of anoxic events (sapropels), Earth-Sci. Rev., 143, 62-97.

Rosenthal, Y., et al. (2004), Interlaboratory comparison study of $\mathrm{Mg} / \mathrm{Ca}$ and $\mathrm{Sr} / \mathrm{Ca}$ measurements in planktonic foraminifera for paleoceanographic research, Geochem. Geophys. Geosyst., 5, Q04D09.

Roveri, M., Flecker, R., Krijgsman, W., Lofi, J., Lugli, S., Manzi, V., Sierro, F.J., Bertini, A., Camerlenghi, A., De Lange, G., Govers R., Hilgen F.J., Hübscher, C., Meijer, P.T., \& Stoica, M. (2014), The Messinian Salinity Crisis: Past and future of a great challenge for marine sciences. Marine Geology. 352, 25-58.

Perch-Nielsen, K., 1985. Cenozoic calcareous nannofossils. In: Bolli, H. M., Saunders, J. B., Perch-Nielsen, K. (Eds.), Plankton Stratigraphy. Cambridge University Press, Cambridge. 427-554.

Schenau, S.J., Antonarakou, A., Hilgen, F.J., Lourens, L.J., Nijenhuis, I.A., Van der Weijden, C.H., Zachariasse, W.J., 1999. Organic-rich layers in the Metochia section (Gavdos, Greece): evidence for a single mechanism of sapropel formation during the past 10 My. Mar. Geol. 153, 117-135. 
Sgarrella, F., Moncharmont, Zei M., 1993. Benthic foraminifera of the Gulf of Naples (Italy): systematics and autoecology. Bollettino della Societa Paleontologica Italiana 32, 145-264.

Sierro, F.J., Hilgen, F.J., Krijgsman, W., Flores, J.A., 2001. The Abad composite (SE Spain): a Mediterranean and global reference section for the Messinian. Palaeogeogr. Palaeoclimatol. Palaeoecol. 168, 141-169.

Sierro, F.J., Flores, J.A., Ba'rcena, M.A., Vàzquez, A., Utrilla, R., Zamarrenõ, I., 2003. Orbitally-controlled oscillations in the planktic communities and cyclical changes in western Mediterranean hydrography during the Messinian. Palaeogeogr. Palaeoclimatol. Palaeoecol. 190, 289-316.

Sprovieri, M.B.R.A., Manta, D.S., Bellanca, Neri, R., Lirer, F., Taberner, C., Pueyo, J.J., Sammartino, S., 2008. $\mathrm{Ba} / \mathrm{Ca}$ evolution in water masses of the Mediterranean late Neogene paleoceanography, 23, 3205.

Takahashi, K., Okada, H., 2000.The paleoceanography for the last 30,000 years in the southeastern Indian Ocean by means of calcareous nannofossils Marine Micropaleontology, 40, 83-103.

Triantaphyllou, M.V., Ziveri, P., Gogou, A., Marino, G., Lykousis, V., Bouloubassi, I., Emeis, K.C., Kouli, K., Dimiza, M., Rosell-Mele, A., Papanikolaou, M., Katsouras, \& G., Nunez, N., 2009. Late Glacial-Holocene climate variability at the south-eastern margin of the Aegean Sea. Marine Geology. 266, 182-197.

Troelstra, S.R., Van der Poel, H.M., Huisman, C.H.A., Geerlings, L.P.A., Dronkert, H., 1980. Paleoecological changes in the latest Miocene of the Sorbas Basin, S.E. Spain. Geol. Mediterr. 8, 115-126.

Van der Laan, E., Gaboardi, S., Hilgen, F.J., Lourens, L.J., 2005. Regional climate and glacial control on highresolution oxygen isotope records from Ain El Beida (latest Miocene, NW Morocco): a cyclostratigraphic analysis in the depth and time domain. Paleoceanography 20, PA1001.

van de Poel, H.M., 1992. Foraminiferal biostratigraphy of the Carboneras-Nijar Basin, Scripta Geol. 102

Van Morkhoven, F. P. C. M., Berggren, W. A., Edwards, A. S., 1986. Cenozoic cosmopolitan deep-water benthic foraminifera. Bulletin des centres de recherches exploration- production Elf-Aquitaine. 11, 1-421.

Van der Zwaan, G.J., Duijnstee, I.A.P., den Dalk, M., Ernst, S.R., Jannink, N.T., Kouwenhoven, T.J., 1999. Benthic foraminifers: proxies or problems? A review of paleoecological concepts. Earth Sci. Rev. 46, 213236.

Wade, B. S., Bown, P. R., 2006. Calcareous nannofossils in extreme environment: the Messinian Salinity Crisis, Polemi Basin, Cyprus. Palaeogeography, Palaeoclimatology, Palaeoecology. 233, 271-286.

Yu, J., J. Day, M. Greaves, Elderfield, H., (2005). Determination of multiple element/calcium ratios in foraminiferal calcite by quadrupole ICP - MS, Geochem. Geophys. Geosyst., 6, Q08P01.

Ziveri, P., Baumann, K.-H., Bockel, B., Bollmann, J., Young, J. R., 2004. Present day coccolithophore biogeography of the Atlantic Ocean. In: Thierstein, H. R., Young, J. R. (Eds.), Coccolithophores: From Molecular Processes to Global Impact. Springer Verlag. 529-562.

\section{Highlights}

-Sapropel and diatomite deposition in the Sorbas Basin

-The MSC-CN bioevent is recorded in the Western Mediterranean

-The MSC-CN bioevent marks the last restriction step of the Mediterranean Basin 

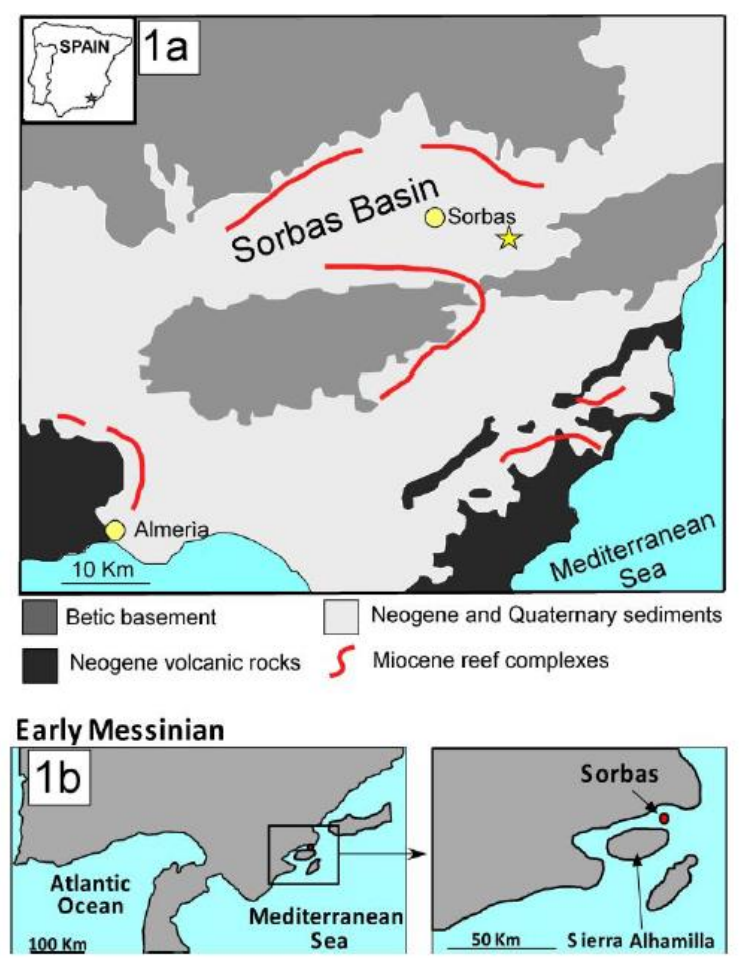

Fig. 1A: Geological map of South-East Spain (modified after Cuevas Castell et al., 2007 and Bourrillot et al., 2009). Star marks the studied section (Perales section).

Fig. 1B: Sorbas Basin Paleogeography during early Messinian (modified after Sánchez-Almazo et al., 2007) 
Perales section (This study)

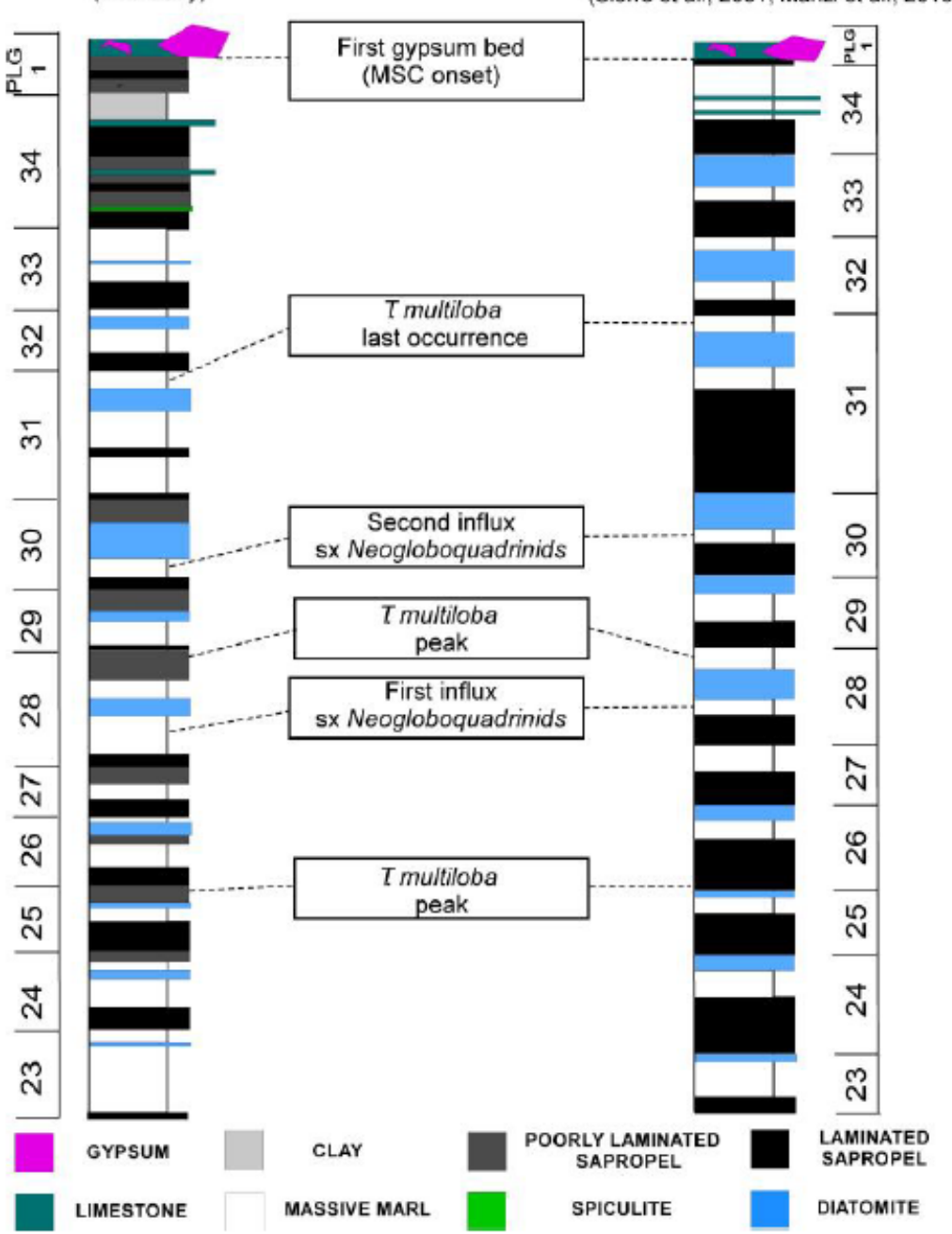

Fig. 2. Correlation with the Perales section achieved by Sierro et al. (2001) modified after Manzi et al. (2013). Foraminifers bioevent (Sierro et al., 2001) and the first gypsum bed (Manzi et al., 2013) are used as tie point. The Turborotalita multiloba last peak and the second influx of Neogloboquadrina acostaensis (sinistral coiling) are recorded in the upper and lower marl of the UA31 and UA30, respectively. These calcareous plankton events are synchronous throughout the Mediterranean (Sierro et al., 2001). Using these bioevents according to Sierro et al. (2001) and the recognition of the PLG1 layer, according to Manzi et al. (2013) it was possible to achieve the correlation with the Abad composite section proposed by Sierro et al. (2001). 

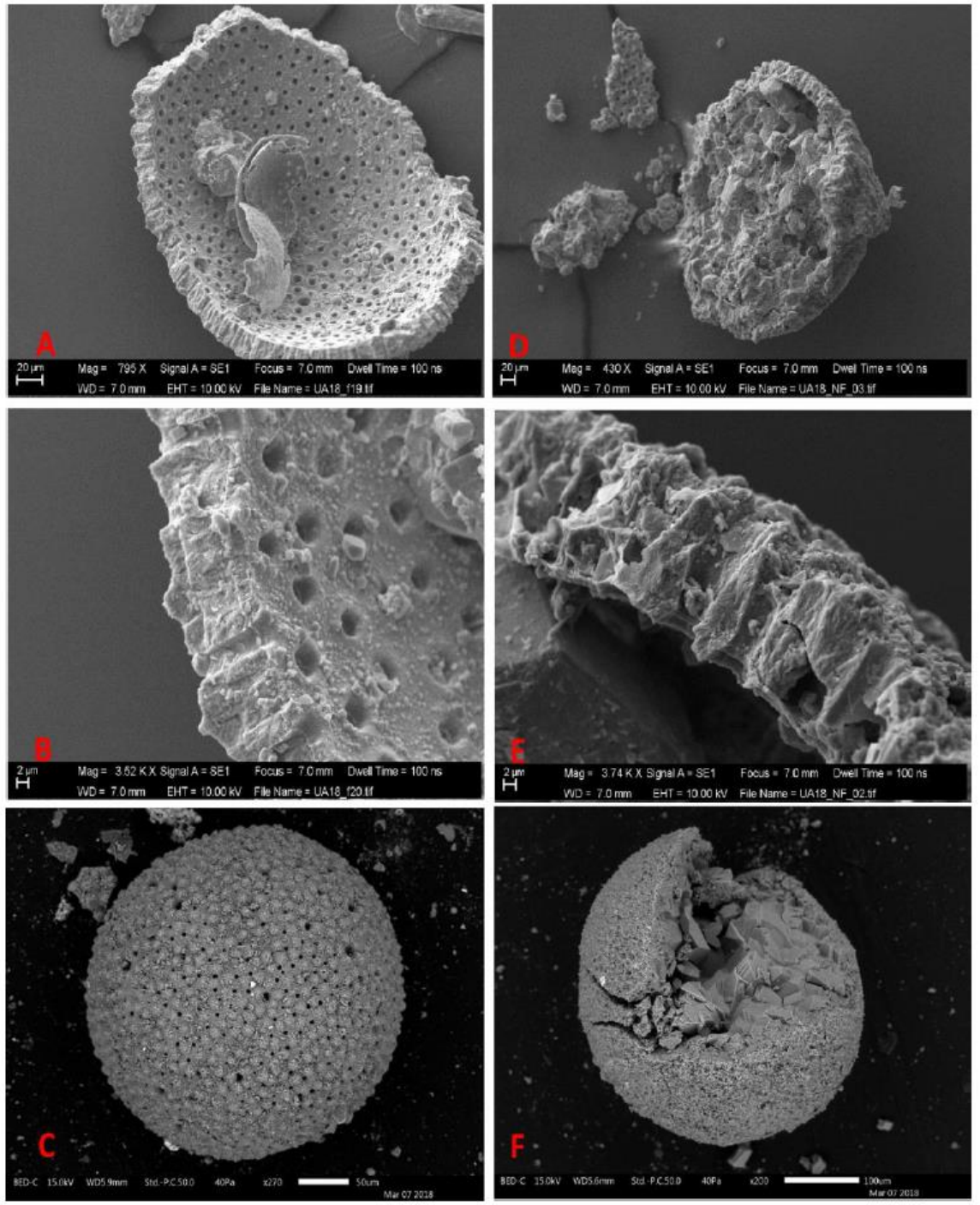

Fig.3.: SEM images of the foraminiferal species $O$. univers $a$ with different degrees of preservation.

(A-B-C): Floating $O$. universa (see 3.4) before the cleaning process, showing good preservation. The internal and external wall are affected by minor diagenetic secondary calcite and coccolith biogenic calcite. Reghizzi et al. 2017 show the effectiveness of the weak acid leach step in removing these kinds of fouling. (D$\mathrm{E}-\mathrm{F}$ ): Sinking $O$. universa (see 3.4) showing bad preservation. The foraminer is completely filled with secondary diagenetic calcite. 


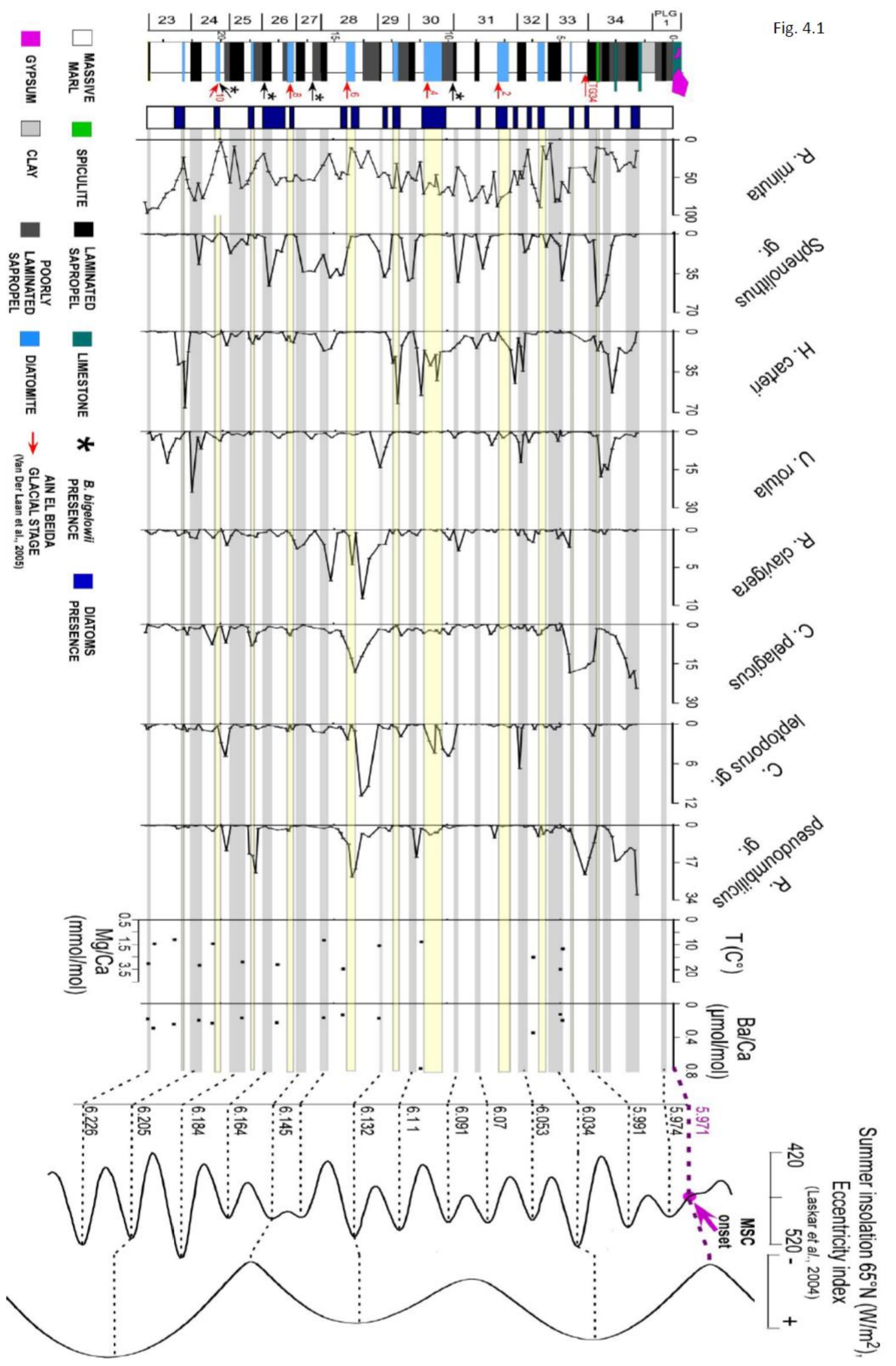




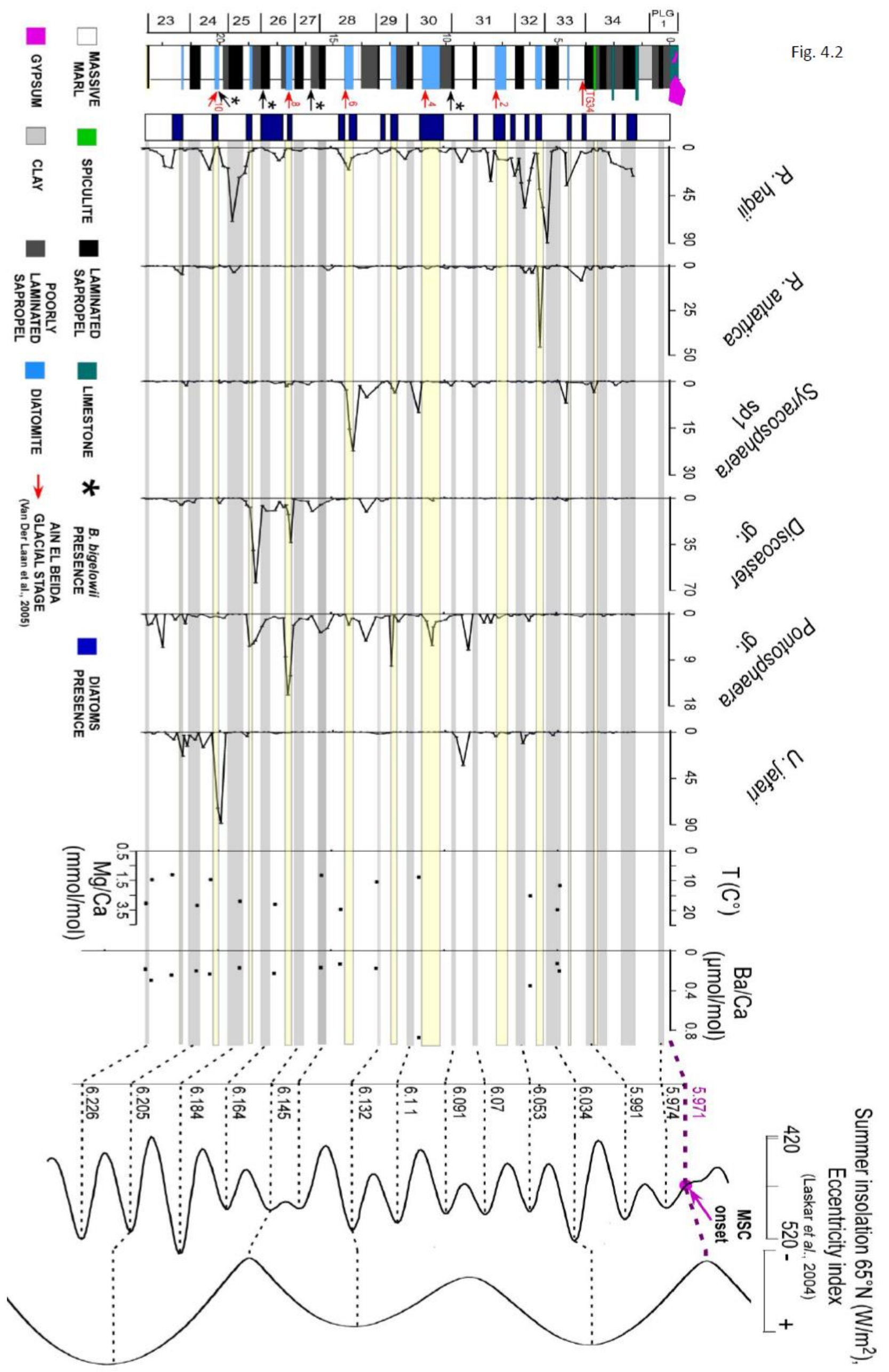


Fig. 4.1; 4.2: CN Relative abundance compared with the $\mathrm{Mg} / \mathrm{Ca}$ and $\mathrm{Ba} / \mathrm{Ca}$ performed on $O$. universa and with orbital variation parameters (Laskar et al., 2004) and the glacial stage inferred from planktic and benthic $\delta^{18} \mathrm{O}$ (red arrows, van der Laan et al., 2005). Blue rectangles indicate diatoms presence in the observed smear-slide. The number on the right line indicate the time expressed in Ma.

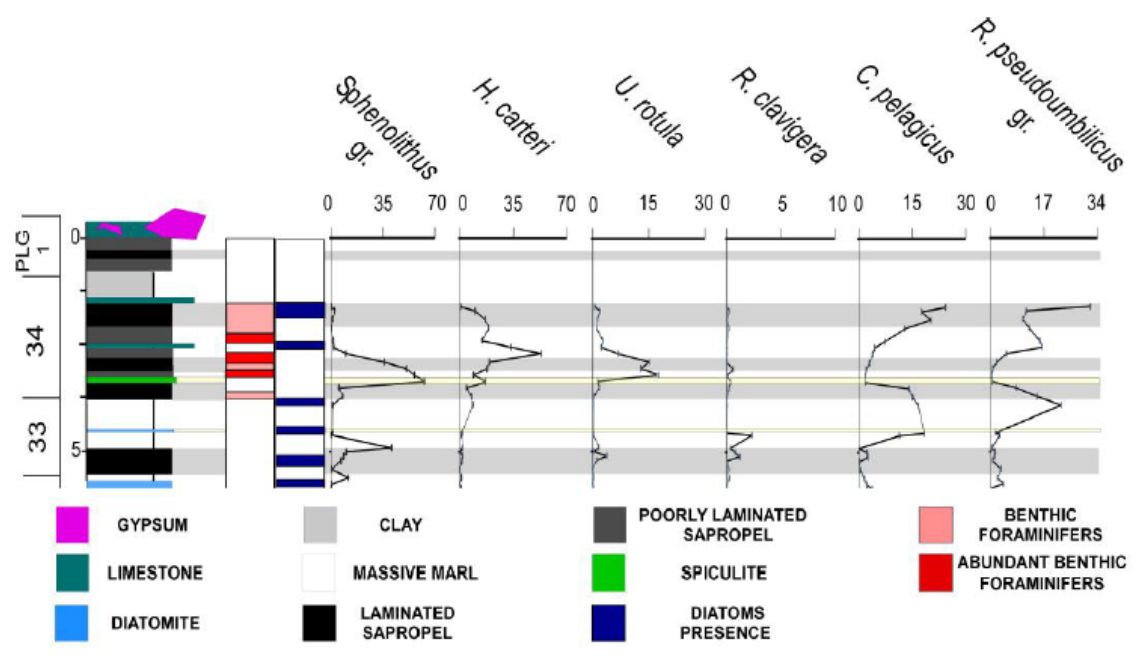

Fig. 5: Semi-quantitave benthic foraminiferal analysis performed in the cycle UA34. The benthic assemblage is dominated by the taxa Bolivina and Bulimina 

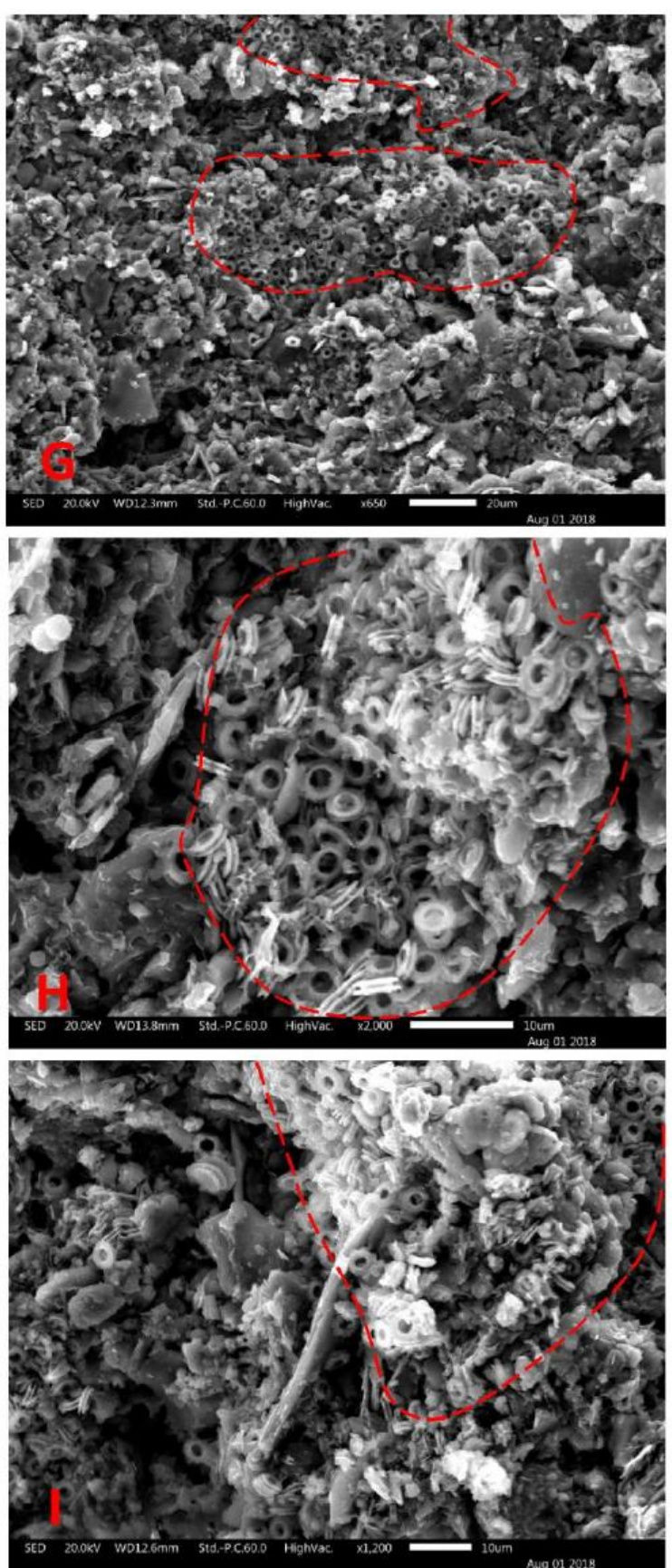

Fig. 6: SEM analyses of the samples containing the MSC bioevent (cycle UA34, U. rotula peak). G-H-I: Faecal pellet containing cluster of coccoliths (mostly U. rotula) embedded in a silica-rich matrix. 
Sphenolithus gr.

\begin{tabular}{|c|c|c|c|}
\hline AUTHOR/S & TIME INTERVAL & $\begin{array}{c}\text { LOCATION } \\
\text { STUDIED }\end{array}$ & ECOLOGICAL PREFERENCES \\
\hline Perch Nielsen, 1985 & Cenozoic & Synthesis & $\begin{array}{c}\text { Warm/oligotrophic } \\
\text { water column }\end{array}$ \\
\hline Mejia-Molina et al., 2010 & $\begin{array}{c}\text { Upper Eocene - } \\
\text { Upper Miocene }\end{array}$ & $\begin{array}{c}\text { Northern } \\
\text { Colombia, } \\
\text { Caribbean sea }\end{array}$ & $\begin{array}{c}\text { Warm/oligotropic, } \\
\text { stratified water column }\end{array}$ \\
\hline Aubry et al., 1992 & Lliocene & $\begin{array}{c}\text { Ceara Rise } \\
\text { (South Atlantic) }\end{array}$ & $\begin{array}{c}\text { Warm/oligotrophic, } \\
\text { stratified water column, } \\
\text { DCM presence }\end{array}$ \\
\hline Wade \& Bown, 2006 2004 & Messinian & Review & $\begin{array}{c}\text { Open and well } \\
\text { oxygenated marine } \\
\text { conditions }\end{array}$ \\
\hline Lozar et al., 2010 & Messinian & Piedmont \\
(Italy) & $\begin{array}{c}\text { Migh salinity fluctuations, } \\
\text { shallow environment } \\
\text { column }\end{array}$ \\
\hline Flores et al., 2005 & Messinian & Sorbas (Spain) & Warm/oligotrophic \\
\hline Whis study & Sorbas (Spain) & $\begin{array}{c}\text { Warm/stratified water } \\
\text { column, DCM presence }\end{array}$ \\
\hline
\end{tabular}

Umbilicosphaera rotula

\begin{tabular}{|c|c|c|c|}
\hline AUTHOR/S & TIME INTERVAL & $\begin{array}{l}\text { LOCATION } \\
\text { STUDIED }\end{array}$ & ECOLOGICAL PREFERENCES \\
\hline $\begin{array}{l}\text { Ziveri et al., } 2004 \\
\text { (Umbilicosphaera } \\
\text { sibogae var. sibogae) }\end{array}$ & Living & Atlantic & Oligotrophic water column \\
\hline $\begin{array}{l}\text { Ziveri et al., } 2004 \\
\text { (Umbilicosphaera } \\
\text { sibogae var. foliosa) }\end{array}$ & Living & Atlantic & Mesotrophic water column \\
\hline $\begin{array}{l}\text { Guerreiro et al., } 2017 \\
\text { (Umbilicosphaera spp.) }\end{array}$ & Living & North Atlantic & $\begin{array}{c}\text { Upper photic zone } \\
\text { dweller }\end{array}$ \\
\hline $\begin{array}{l}\text { Alves et al., } 2016 \\
\text { (Umbilicosphaera spp.) }\end{array}$ & Miocene & $\begin{array}{l}\text { Campos Basin } \\
\text { (South Atlantic) }\end{array}$ & Eutrophic water column \\
\hline Flores et al., 2005 & Messinian & Sorbas (Spain) & $\begin{array}{l}\text { Nutrient decreasing, } \\
\text { stable pycnocline } \\
\text { development }\end{array}$ \\
\hline This study & Messinian & Sorbas (Spain) & $\begin{array}{l}\text { Eutrophic upper water } \\
\text { column }\end{array}$ \\
\hline
\end{tabular}




\section{Rhabdosphaera clavigera}

\begin{tabular}{|c|c|c|c|}
\hline AUTHOR/S & TIME INTERVAL & $\begin{array}{l}\text { LOCATION } \\
\text { STUDIED }\end{array}$ & ECOLOGICAL PREFERENCES \\
\hline Ziveri et al., 2004 & Living & Atlantic & $\begin{array}{l}\text { Warm/oligotrophic } \\
\text { surface water }\end{array}$ \\
\hline Haidar \& Thierstein, 1997 & Living & North Atlantic & $\begin{array}{l}\text { Opportunistic, warm water, } \\
\text { high light intensity tolerant }\end{array}$ \\
\hline Malinverno et al., 2003 & Living & $\begin{array}{c}\text { East } \\
\text { Mediterranean }\end{array}$ & $\begin{array}{c}\text { Warm water, } \\
\text { upper photic zone } \\
\text { dweller }\end{array}$ \\
\hline Dimiza et al., 2008 & Living & $\begin{array}{c}\text { East } \\
\text { Mediterranean }\end{array}$ & $\begin{array}{l}\text { Upper photic } \\
\text { zone dweller }\end{array}$ \\
\hline Silva et al., 2008 & Living & $\begin{array}{l}\text { North Atlantic } \\
\text { (Portogual coast) }\end{array}$ & $\begin{array}{l}\text { Stable and stratified } \\
\text { water column }\end{array}$ \\
\hline Negri et al., 1998 & $\begin{array}{l}\text { Tortonian - } \\
\text { Messinian }\end{array}$ & $\begin{array}{l}\text { M. Del Casino } \\
\text { (Italy) }\end{array}$ & $\begin{array}{c}\text { Opportunistic, } \\
\text { nutrient decreasing }\end{array}$ \\
\hline Flores et al., 2005 & Messinian & Sorbas (Spain) & $\begin{array}{l}\text { Warm/oligotrophic } \\
\text { water column }\end{array}$ \\
\hline This study & Messinian & Sorbas (Spain) & $\begin{array}{l}\text { Seasonal proliferation with } \\
\text { high spring temperature and } \\
\text { decreasing nutrients } \\
\text { conditions }\end{array}$ \\
\hline
\end{tabular}

Helicosphaera carteri

\begin{tabular}{|c|c|c|c|}
\hline AUTHOR/S & TIME INTERVAL & $\begin{array}{c}\text { LOCATION } \\
\text { STUDIED }\end{array}$ & ECOLOGICAL PREFERENCES \\
\hline Ziveri et al., 2004 & Living & Transects & $\begin{array}{c}\text { Warm and } \\
\text { mesotrophic water } \\
\text { column }\end{array}$ \\
\hline Giraudeau, 1992 & Living & South Atlantic & $\begin{array}{c}\text { Eutrophic and } \\
\text { hyposaline water } \\
\text { column }\end{array}$ \\
\hline Crudeli et al., 2006 & $\begin{array}{c}\text { Late } \\
\text { Holocene }\end{array}$ & $\begin{array}{c}\text { Mediterranean } \\
\text { West }\end{array}$ & $\begin{array}{r}\text { Middle photic zone } \\
\text { dweller }\end{array}$ \\
\hline Flores et al., 2005 & Messinian & Sorbas (Spain) & $\begin{array}{r}\text { Cool and mesotrophic } \\
\text { water column }\end{array}$ \\
\hline This study & Messinian & Sorbas (Spain) & $\begin{array}{r}\text { Mesotrophic } \\
\text { water column, salinity } \\
\text { fluctuations }\end{array}$ \\
\hline
\end{tabular}

Fig. 7: Ecological preferences inferred for the $\mathrm{CN}$ involved in the MSC CN bioevent coming from previous and this study. 


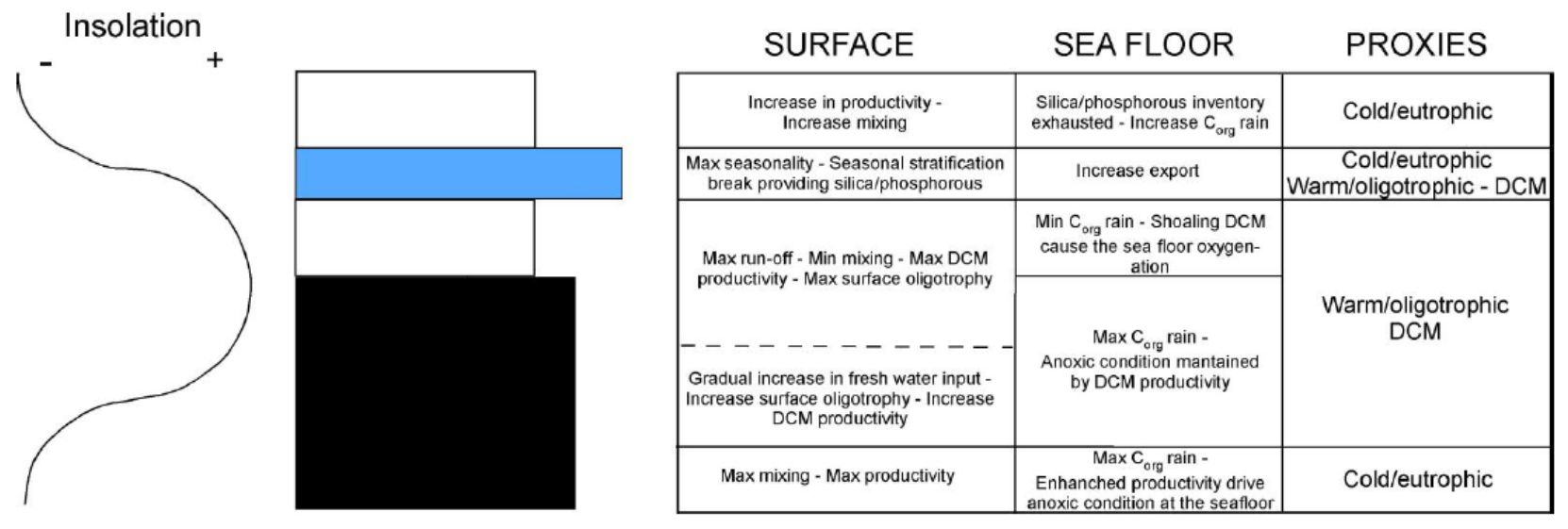

Fig. 8: Depositional model of the quadripartite precessional cycle in the Upper Abad member. The reconstruction of the surface water column and sea floor condition is achieved comparing our results with previous from Sierro et al. (2003); Pèrez-Folgado et al. (2003); Flores et al. (2005); Filippelli et al. (2005) and Reghizzi et al., (2017). $C_{\text {org }}=$ Organic Carbon 